\title{
Environmental, Geotechnical and Hydraulic Behaviour of a Cellulose-rich By-product Used as Alternative Cover Material
}

By

Cláudia Teixeira Panarotto, Alexandre Rodrigues Cabral and Guy Lefebvre

C.T. Panarotto. Universidade de Caxias do Sul, Departement of Chemical Engineering, C.P. 1352, Caxias do Sul, RS 95001-970, Brazil

\author{
A.R. Cabral ${ }^{1}$ and G. Lefebvre \\ Department of Civil Engineering \\ Faculty of Engineering, Université de Sherbrooke \\ 2500, boul. de l'Université, Sherbrooke, Quebec, Canada J1K 2R1 \\ ${ }^{1}$ Corresponding author (e-mail alexandre.cabral@usherbrooke.ca)
}

Word count: 8576 (excluding list of Figures)

Panarotto, C.T., Cabral, A.R., Lefebvre, G. (2005). Environmental, geotechnical and hydraulic behaviour of a Cellulose-rich By-product Used as Alternative Cover Material. Journal of Environmental Engineering and Science, vol. 4, 123-138 
Abstract: Deinking by-product (DBP), a cellulose-rich by-product produced in the early stages of the paper recycling process, has been used as alternative material for the construction of cover systems for municipal waste disposal facilities and acid-producing mine residues. Considering the high organic content of this material, covers constructed with it are susceptible to biodegradation, thus to changes in their properties with time. With the goal of identifying the biodegradation parameters that could influence the long term behaviour of DBP covers, an experimental laboratory program was developed and a series of 15 samples of DBP were monitored in biodegradation tests, for 400 days. Periods of intermittent water percolation allowed for collection of leachate. The evolution of gas and leachate production was monitored in terms of quality and quantity. According to the results obtained, the hydraulic and geomechanical properties of importance for a cover do not seem to be adversely affected by the level of biodegradation of the DBP or by mass loss.

Key words: Cover systems, deinking by-products, biodegradation, mass loss by gas production, mass loss by leaching 


\section{INTRODUCTION}

Cover systems in municipal waste disposal facilities (MWDF) help control infiltration, whereas in the case of mining residues, the final cover must reduce the influx of oxygen that can lead to the generation of acid mine drainage (Cabral et al. 2000). In both cases, it is technically possible - and often an economic advantage - to use recycled materials or industrial by-products as alternative materials in the cover system, ultimately reducing their disposal in dedicated landfills (CQVB 1996; Wiegand and Unwin 1994). The beneficial use of deinking by-products (DBP), which are generated in large quantities by the pulp and paper industry and which used to be disposed of in dedicated landfills, is an example where an industrial by-product can replace fine-grained materials as infiltration control barrier, while helping to reduce landfilling costs.

DBP, also known as fiber-clay, are composed mainly of cellulose fibres, clay and calcite. The amount of fibres and the overall composition varies significantly with the type of paper recycled and the efficiency of the deinking process employed (Latva-Somppi et al. 1994). DBP have been characterized by many researchers, including Vlyssides and Economides (1997), Latva-Somppi et al. (1994) and Ettala (1993). This highly compressible by-product usually leaves the production plant with gravimetric water contents varying from 100 to $190 \%$. The volatile matter content ranges from $48 \%$ to $60 \%$ and the relative density (Dr; this parameter is also know as specific gravity, whose symbol is Gs) is generally in the range of 1.8 to 2.0 . These values are similar to data found in literature (Cabral et al. 1998; Kraus et al. 1997; Moo-Young and Zimmie 1996).

While composting remains an option in terms of beneficial reuse, the significant mineral and fibre content of this by-product allows other economically sound reuse alternatives. This is particularly the case when the material is used as replacement for fine-grained soils in the 
construction of cover systems in MWDF and for mining tailings that produce acid mine drainage (AMD). Indeed, DBPs have been acknowledged to perform quite well as barriers to infiltration in sanitary landfills in the United States (Floess et al. 1995; Kraus et al. 1997; LaPlante 1993; Malmstead et al. 1999; Maltby and Eppstein 1994; Zimmie and Moo-Young 1995), Japan (Kamon et al. 2002), South Africa (Brown et al. 1998) and Canada (Audet et al. 2002). DBP have also performed quite effectively as an oxygen barrier layer to prevent AMD (Cabral et al. 2004; Cabral et al. 2000). The DBP barrier limits oxygen from reaching the tailings mass due to the high degree of saturation that can be maintained, but also due to aerobic degradation of its organic matter. Aerobic degradation implies oxygen consumption. If $\mathrm{O}_{2}$ is consumed, less of it reaches the tailings under the DBP cover. Indeed, considering the high organic content of this material, such barriers are susceptible to biodegradation, thus to changes in their properties with time. There is, however, very little data concerning the evolution with time of biodegradation of DBP barriers. Several uncertainties also exist concerning prediction of its long term behaviour. This paper presents and discusses the results of laboratory tests aimed at evaluating the long term biodegradation behaviour of DBP, as well as the implications of the evolution of DBP on key geotechnical parameters and properties.

\section{MATERIALS AND METHODS}

An experimental laboratory program was developed with the aim of identifying the biodegradation parameters that could influence the long term geotechnical and hydraulic behaviour of DBP. It included a series of 15 samples that were monitored during 400 days. Periods of intermittent water percolation (herein denominated leaching periods) allowed for lea- 
chate collection. The evolution of gas and leachate production was monitored in terms of quality and quantity.

The initial degrees of saturation, density and water contents of the samples were similar to those found in actual DBP layers placed in the field (Table 1). However, 12 of the tests were performed under much higher temperatures $\left(38^{\circ} \mathrm{C}\right)$ to accelerate the degradation process. This temperature is considered optimal for the activity of anaerobic (methanogenic) micro-organisms (Hartz et al. 1982; Zeikus and Winfrey 1976). Three control cells were prepared: two were tested at $21^{\circ} \mathrm{C}$ and one at $12^{\circ} \mathrm{C}$. At $21^{\circ} \mathrm{C}$, the prevailing temperature in the upper part of the DBP layer during the summer and fall was simulated, while at $12^{\circ} \mathrm{C}$, the temperature in the middle and at the base of a DBP layer was simulated (Cabral et al. 1999).

After each leaching period, two of the cells placed at $38^{\circ} \mathrm{C}$ were disassembled. The direct mass loss of the disassembled cells was determined and several parameters obtained, such as water content, relative density and organic matter content (cellulose, hemi-cellulose and lignin). In addition, the following geotechnical parameters were obtained: void ratio, degree of saturation, relative density and density water content relationship (Proctor curve). The materials and methods employed are described as follows.

\section{Materials}

The compositions of the DBP used in the experiments described below are presented in Figure 1. It can be observed that a large portion of the material is composed of organic matter and that calcite dominates the inorganic fraction. 


\section{Experimental equipment}

Fourteen $5 \mathrm{~mm}$-thick PVC biodegradation cells were constructed, each with a volume of 9.5 litres. The size of the samples was determined based on the need to perform various geotechnical and physico-chemical characterization tests after the end of each accelerated biodegradation test. One of the control cells was constructed of Plexiglas with a total volume of 4.1 litres and placed at $12^{\circ} \mathrm{C}$. A schematic drawing of the cell is presented in Figure 2. The dimensions in brackets correspond to those of the control cell at $12^{\circ} \mathrm{C}$. The design was made bearing in mind that deaerated, deionized, distilled water was to be percolated through the samples at certain times and that leachate was to be collected. To do so, the cells were designed with two chambers, one on top and the other below the sample (Figure 2). Water intake took place at point $\mathrm{A}$, leachate collection at point $\mathrm{D}$ and gas sampling at point $\mathrm{B}$. At points $\mathrm{A}, \mathrm{C}$ and $\mathrm{D}$ quick connect type valves were installed allowing for complete waterproofing of the cells. Biogas was collected from both chambers. Thermocouples were installed in five cells allowing for the temperature within the cells to be measured. The temperatures varied less than $0.5^{\circ} \mathrm{C}$ for the cells placed at $38{ }^{\circ} \mathrm{C}$, whereas in the case of the control cells, variations of almost $3{ }^{\circ} \mathrm{C}$ were measured.

\section{Sample preparation and testing}

After mixing several samples delivered to the laboratory, random sub-samples were taken for physico-chemical characterization, which included: water content, relative density and organic matter content (cellulose, hemi-cellulose and lignin). Sample compaction was performed in a manner that aimed at reproducing field conditions as closely as possible in terms of density and water content (thus degree of saturation and void ratio). The sequence and energy prescribed in the ASTM D698 procedure (ASTM 2000) was employed. After compaction in 3 layers, the 
cells were hermetically sealed, with a layer of silicon applied to the cover. The general conditions of the 15 samples are presented in Table 1. The averages and standard deviations of the different parameters are presented. The data referring to the control cell at $12^{\circ} \mathrm{C}$ (Plexiglas cell) are also presented in Table 1.

\section{Gas sampling and analysis}

As shown in Figure 2, bags were attached to the cells for storage and removal of the biogas generated. The bags, manufactured by Pollution Measurement Corporation, are made of laminated polyethylene with two outlets, one attached to the cell and the other permitting the removal of gas through a septum. The volume and biogas (actually $\mathrm{O}_{2}, \mathrm{CO}_{2}$ and $\mathrm{CH}_{4}$ ) composition of the cells were determined every day or every three days, during the first months of the experiment. Afterwards, these analyses were done once a week. To collect gas samples, 60 ml syringes were used.

The concentrations of the three gases were measured with a LFG-20 apparatus (Triple Landfill Gas Analyser) from ADC-Analytical Company Ltd. The precision of the apparatus is \pm $0.4 \%$ for oxygen. For $\mathrm{CO}_{2}$ and $\mathrm{CH}_{4}$, the precision varies depending on the magnitude of the readings: from 0 to $10 \%$, the precision is $\pm 0.5 \%$, whereas from 10 to $100 \%$ it is $\pm 3.0 \%$. After calibration, the LFG-20 was purged with pure nitrogen and the gas in the syringe was injected in it. Gas measurements were done in triplicate. Once the composition of the gases had been analysed, the bags were emptied using a $500 \mathrm{ml}$ syringe. The volumes were then corrected to the standard temperature and pressure. 


\section{Water percolation, sampling and characterization}

The tests were divided into sequences of flow (water percolation) and no flow, as is the case in actual field conditions. During leaching periods, which occurred $20 \%$ of the time, approximately one equivalent volume of voids (EVV) was percolated through the sample under a hydraulic gradient close to unity. One EVV is equivalent to the porosity volume of the sample. In the present case, $1 \mathrm{EVV}$ is equal to approximately 4 litres.

For each EVV collected, the following analyses were performed as described in APHA Standard Method (1995) (APHA or other methods are indicated in parenthesis): $\mathrm{pH}\left(4500-\mathrm{H}^{+} \mathrm{B}\right.$ - electrometric method), total solids content (2540-B), total volatile solids (2540-E), dissolved solids (2540-C), dissolved volatile solids (2540-C), the chemical oxygen demand (5220-D), volatile organic acid contents (potentiometric titration - calculated based on alkalinity; DiLallo and Albertson 1961), and the calcium concentration ( using a Varian AA1275 atomic absorption spectrometer).

\section{Cell opening and sample exhumation}

During the 400 days of the tests, four groups of two cells (all placed at $38^{\circ} \mathrm{C}$ ) were opened after the leaching periods. The control cells, placed at $21^{\circ} \mathrm{C}$ and at $12^{\circ} \mathrm{C}$, were also opened after 400 days. The remaining samples are still being monitored.

When the cells were opened, measurements were taken to calculate the final volume of the sample. Sub-samples were then taken from each of the three layers in which the samples had initially been compacted. The sub-samples were packaged in plastic bags and weighed. The water content and volatile solid content of each layer was determined. The water content was determined by drying at $110 \pm 5^{\circ} \mathrm{C}$, in accordance with the CAN/BNQ 2501-070-M-86 (Bureau de Normalisation du Québec 1986b) procedure. The volatile matter content was determined 
according to the ASTM D2974-C (ASTM 1987) standard. Further details pertaining to the procedure of cell opening are described by Teixeira (2001).

The mineral composition of the material was performed using a Rigaku D max/B X-ray diffractometer and a 1410-X Ray Spectometer (fluorescence). A crosscheck of the mineral content was done by differential thermogravimetric analysis (TG/DTA). The organic composition (cellulose, hemi-cellulose and lignin) of the DBP used in the experiments was determined by acid hydrolysis, which solubilizes sugar monomers. The sugar monomers were analyzed by High Performance Liquid Chromatography (HPLC) using a Dionex DX-500 apparatus equipped with a Dionex PA-10 column, a PA-10 pre-column and a pulsating amperometric detector. The lignin content was determined from the same hydrolysed samples using a variation of the ASTM E1721-01 Klason lignin method (ASTM 2001).

\section{Evaluation of mass loss by leaching and gas production}

Mass loss by leaching was determined by multiplying the total solids concentration in the leachate by the volume collected. It is expressed in terms of absolute mass loss and as a percentage of the total mass of the sample. The mass loss by gas production was calculated for each gas sample collected, and from the volumes of dissolved $\mathrm{CO}_{2}$ and $\mathrm{CH}_{4}$ in the collected water. The volumes in the gas bags and of the gas dissolved in water were transformed into mass by using the perfect gas law and their molecular weight. The amounts of dissolved gases were calculated by applying Henry's Law (Tchobanoglous et al. 1993). The mass losses due to gas production were also expressed in terms of absolute mass loss and percentage of the mass of the sample. 


\section{Basic geotechnical characterization}

The geotechnical characterization includes the determination of water content, void ratio, degree of saturation, relative density and the density water content relationship (Proctor curve). This characterization was done for the fresh samples and for the samples submitted to controlled degradation, i.e. samples collected after cell opening. The Proctor Standard tests were conducted according to the ASTM D698 (ASTM 2000) standard. The specific weight of solids was obtained according to the procedure CAN/BNQ 2501-070-M-86 (Bureau de Normalisation du Québec 1986a).

\section{RESULTS}

\section{Evolution of biogas production and composition}

Figure 3 presents the total accumulated production of $\mathrm{CO}_{2}$ and $\mathrm{CH}_{4}$ as a function of time, for the tests at $38^{\circ} \mathrm{C}$. The leaching periods and number of samples considered to calculate the averages are also indicated. In the case of the $1^{\text {st }}$ period, instead of $12(n=12)$, only 10 cells $(n=10)$ were considered due to a problem with the gas collection system for two cells.

A total average volume of $60.7 \pm 5.4$ litres of gas per kilogram of dry DBP (herein noted as $1 . \mathrm{kg}^{-1} \cdot \mathrm{j}^{-1}$-dry basis) was measured in 400 days. The total $\mathrm{CO}_{2}$ production measured was $30.5 \pm$ 2.41 , whereas that of the $\mathrm{CH}_{4}$ was $23.8 \pm 2.71$. On average, the production of $\mathrm{CO}_{2}$ and $\mathrm{CH}_{4}$ is responsible for $91 \%$ of the total volume of gas produced. The non characterized $9 \%$ very likely consists of other gases formed during anaerobic degradation, such as ammonia, hydrogen, sulphites, mercaptans, and others (Tchobanoglous et al. 1993).

Observation of Figure 3 shows that gas production begins following a rate of $0.51 . \mathrm{kg}^{-1} \cdot \mathrm{j}^{-1}$

-dry basis. $\mathrm{CO}_{2}$ is by far the most important component. The period between the 15 th and $17^{\text {th }}$ 
days, that precedes the start of $\mathrm{CH}_{4}$ production, is characterized by a significant slowdown in gas production. Starting on the $27^{\text {th }}$ day, gas production resumed with the appearance of $\mathrm{CH}_{4}$. From the $27^{\text {th }}$ day, the rate of production lowered $\left(0.111 . \mathrm{kg}^{-1} \cdot \mathrm{j}^{-1}\right.$-dry basis), as is shown in Figure 3. The rate of $\mathrm{CH}_{4}$ production remained constant until the $400^{\text {th }}$ day.

Figure 4 presents the percentages of $\mathrm{O}_{2}, \mathrm{CO}_{2}$ and $\mathrm{CH}_{4}$ in the gas produced over time. It can be observed that the oxygen was rapidly consumed at the beginning of the test, while $\mathrm{CO}_{2}$ production was intense. Around the $20^{\text {th }}$ day, $\mathrm{CO}_{2}$ represented approximately $90 \%$ of the total gases produced. Methane production started around the $27^{\text {th }}$ day, following a short transition period during which gas production stalled. Its concentration rapidly increased and around the $60^{\text {th }}$ day $\mathrm{CH}_{4}$ represented $40 \%$ of the biogas produced. Around the $90^{\text {th }}$ day, the concentration of $\mathrm{CH}_{4}$ surpassed that of $\mathrm{CO}_{2}$. It is important to note that the leaching periods are responsible for the oscillations of $\mathrm{CO}_{2}$ concentration, due to the dissolution in water.

Figure 5 presents total gas production measured over time, for different temperatures. As in other biological processes, anaerobic degradation is affected by temperature (Christensen and Kjeldsen 1989). As expected, gas production was the highest at $38^{\circ} \mathrm{C}$. At $21^{\circ} \mathrm{C}$, around 401 of gas per kg of dry DBP were produced. This production represents two thirds of the production at $38^{\circ} \mathrm{C}$. At $12^{\circ} \mathrm{C}$, the production was clearly lower.

Figure 6 presents the variation over time of the volumetric concentration of $\mathrm{CH}_{4}$ for each testing temperature. Methane appearance occurred on the $27^{\text {th }}$ day for tests at $38^{\circ} \mathrm{C}$, on the $63^{\text {rd }}$ day for tests at $21^{\circ} \mathrm{C}$ and on the $158^{\text {th }}$ day for the tests at $12^{\circ} \mathrm{C}$. Once the $\mathrm{CH}_{4}$ production had begun, the concentrations for the tests at $21^{\circ} \mathrm{C}$ remained below those observed for the tests at $38^{\circ} \mathrm{C}$. In the case of the tests at $12^{\circ} \mathrm{C}$, the concentration increased with time and rose to around $18 \%$ after 400 days. 


\section{Comparison between potential and measured biogas production}

Potential biogas production was calculated to establish a production threshold and to be able to compare it to the production measured during the 400 days of the study. This potential was estimated according to the reaction R1, while putting forward the hypothesis that all the cellulose and hemicellulose convert to gas (Barlaz 1997; Barlaz and Ham 1989; Christensen and Kjeldsen 1989; McBean et al. 1995; Tchobanoglous et al. 1993).

[1] $\mathrm{C}_{a} \mathrm{H}_{b} \mathrm{O}_{c} N_{d}+\left(\frac{4 a-b-2 c+3 d}{4}\right) \mathrm{H}_{2} \mathrm{O} \rightarrow\left(\frac{4 a+b-2 c-3 d}{8}\right) \mathrm{CH}_{4}+\left(\frac{4 a-b+2 c+3 d}{8}\right) \mathrm{CO}_{2}+d N H_{3}$ where the parameters a, b, c and d vary depending on the molecule considered.

Cellulose represents the greatest source for biogas production from DBP, followed by hemicellulose (Figure 1). Considering that lignin is recalcitrant in anaerobic conditions (Young and Frazer 1987), the production of $\mathrm{CO}_{2}$ and $\mathrm{CH}_{4}$ resulting from lignin was considered negligible. As a consequence, its potential of biogas production, which represents $6.6 \%$ of the dry mass of DBP, was not taken into account. As shown in Table 2 the cellulose and hemicellulose masses present in each sample, in the beginning of the tests, can supply 387.51 of $\mathrm{CO}_{2}$ and 299.41 of $\mathrm{CH}_{4}$. In other words, $1.0 \mathrm{~kg}(80 \%$ cellulose, $20 \%$ hemicellulose) can supply 6871 of gas $\left(\mathrm{CO}_{2}\right.$ and $\left.\mathrm{CH}_{4}\right)$. A comparison between the total calculated potential and the actual production obtained during the tests is presented in Table 3. The results presented show the accumulated average volumes of $\mathrm{CO}_{2}$ and $\mathrm{CH}_{4}$ produced and the respective rates of production for each testing temperature. It is noted that the recovery rates (percentage of total potential) are low and decrease as temperature decreases. The rightmost column in Table 3 shows the total accumulated quantities expressed as a percentage of the estimated potential of gas production 
after 400 days $\left(18.3 \%, 12.0 \%\right.$ and $0.3 \%$ for the tests, at 38,21 and $12{ }^{\circ} \mathrm{C}$, respectively). Although temperature influences gas production rates, it is not the only parameter affecting the degradation of DBP; otherwise the gas production rate at $38^{\circ} \mathrm{C}$ would have been higher. Other limiting conditions affecting gas production rates are discussed in the following.

The tests were designed to reproduce compaction conditions in the field. The implications of compaction on gas production are two fold. First, it leads to a low hydraulic conductivity of the DBP samples (Cabral et al. 2002), which means that the pore water is purged out slowly during the leaching periods. Second, it creates a less effective contact between the solid and liquid phases, as compared to suspensions. Boman and Bergstrom (1985) conducted anaerobic degradation studies of DBP in reactors, where $0.4 \mathrm{~g}$ of solids were placed in one liter of water. During the 15 days of the study, Boman and Bergstrom (1985) obtained a biogas production rate of 4801 for each $\mathrm{kg}$ of volatile solids, which is nearly five times higher than the $100 \mathrm{l} / \mathrm{kg}$ produced in 400 days. However, the solids to liquid ratio in the present study was 1:1.7, i.e. three orders of magnitude lower. This creates quite different degradation dynamics resulting in slower gas production rates.

Other factors can be mentioned to explain the relatively slow gas production rates. One is the high C:N ratio, typical of DBP (129:1, in the case of this study). However, Jackson and Line (1997) did not experience any problems composting DBP with C:N ratios as high as 218:1. Another possible inhibitor would be the presence of toxic elements. Several characterization studies performed with DBP (e.g. Ettala 1993; Teixeira 2001; Trépanier et al. 1996; Vlyssides and Economides 1997) have, however, concluded that DBP cannot be considered toxic. 


\section{Evolution of leachate production}

Figure 7 shows the variation over a period of 400 days of $\mathrm{pH}, \mathrm{COD}$, volatile organic acid (VOA) content in the leachate, total solids (TS) and total volatile solids (TVS). The leaching periods and the number of samples (n) considered in the calculation of the averages are also indicated. The $\mathrm{pH}$ increased from 5.5 in the beginning of the $1^{\text {st }}$ leaching period (Figure $7 \mathrm{a}$ ) to approximately 6.5 early during the percolation of the $2^{\text {nd }}$ EVV. COD and VOC (Figure 7a), as well as TS and TVS (Figure 7b), show the same evolution, i.e. a significant decrease after the leaching of the $1^{\text {st }} E V V$. After the leaching of the $2^{\text {nd }} E V V$, the concentrations remained the same until the end of the tests.

During leaching of the $1^{\text {st }} \mathrm{EVV}$, the total solids concentration in the leachate quickly decreased from its initial value of approximately $25000 \mathrm{mg} / 1$ to $11000 \mathrm{mg} / \mathrm{l}$. At the beginning of the second leaching period, undertaken after an interval of 40 days without water percolation, the total solids concentration was as low as $4000 \mathrm{mg} / \mathrm{l}$ and decreased even further to around 1400 $\mathrm{mg} / 1$ at the end of the $2^{\text {nd }}$ EVV. According to Teixeira (2001), approximately $93 \%$ of the total solids are found in the dissolved form.

COD and VOC also decreased between the $1^{\text {st }}$ and $2^{\text {nd }}$ leaching periods. This decrease is explained by the use of dissolved carbon sources in the leachate by micro-organisms, resulting in gas production. Once $\mathrm{CH}_{4}$ started to be produced, the total gas production rate remained constant (Figure 3), although the proportion of $\mathrm{CH}_{4}$ in the gas quickly increased (Figure 4).

As can be observed in Figure 7, the ratio of volatile solids to total solids was 0.53 at the beginning of the $1^{\text {st }}$ leaching period. In other words, a little over half of the solids consisted of volatile solids. By the beginning of the $2^{\text {nd }}$ leaching period, the concentration of TS and TVS had decreased to approximately a third of the value obtained at the end of the $1^{\text {st }}$ period and the 
TVS/TS ratio slightly decreased to 0.5 . The loss of volatile solids can be explained by gas production (Figures 4 to 6), whereas the decrease in non-volatile solids can be partly associated with carbonate precipitating out from the leachate due to an increase in $\mathrm{pH}$ and decrease in VOC (Figure 7b). In addition, carbonates in the leachate are still transformed into $\mathrm{CO}_{2}$ due to the slightly acidic $\mathrm{pH}$. The TVS/TS ratio reached a value of 0.25 at the end of the leaching of the $4^{\text {th }}$ EVV.

Figure 8 shows the evolution of the $\mathrm{pH}, \mathrm{TS}, \mathrm{COD}$ and VOC as a function of time testing temperature. At the beginning of the tests at $38^{\circ} \mathrm{C}$, the $\mathrm{pH}$ was close to 5.5 (the lowest value) then increased to reach approximately 6.5 . For the tests at $21^{\circ} \mathrm{C}$ and $12^{\circ} \mathrm{C}$, the starting $\mathrm{pH}$ was higher than at the beginning of the tests at $38^{\circ} \mathrm{C}$. However, near the end it remained a little bit lower (around 6.0). A decrease in TS and TVS after leaching of the $1^{\text {st }}$ EVV was observed for all temperatures. The greatest drop was observed for the cells at $38^{\circ} \mathrm{C}$, where, at the end of the $4^{\text {th }}$ leaching period, the TS concentration was $1400 \mathrm{mg} / \mathrm{l}$, whereas for the tests at $21^{\circ} \mathrm{C}$ and $12^{\circ} \mathrm{C}$, the TS concentrations remained respectively at $8800 \mathrm{mg} / \mathrm{l}$ and $11000 \mathrm{mg} / \mathrm{l}$. COD and VOC followed the same change pattern observed for the TS with respect to the influence of temperature.

\section{Mass loss by leaching and gas production}

Figure 9 presents the evolution of the total mass loss. At the end of the $1^{\text {st }}$ leaching period, the mass loss due to leaching ( $4 \%$ ) represents $67 \%$ of the total loss $(6 \%)$. After the $1^{\text {st }}$ leaching period, mass loss by leaching becomes negligible (Figure 9). This implies that nonvolatile solid loss also becomes negligible. At the end of the 400 days, the total mass loss was approximately $12 \%$. The loss from gas production increased from $2 \%$, during leaching of the $1^{\text {st }}$ 
EVV to $8 \%$ after 400 days. Therefore, it represents $66 \%$ of the total loss. The loss from gas production occurred even during periods without leaching.

Figure 10 presents the total mass loss as a function of the testing temperature. The results show that there is no marked difference between the total mass loss at $38^{\circ} \mathrm{C}$ and $21^{\circ} \mathrm{C}$. The loss at $12^{\circ} \mathrm{C}$ represents approximately half of those observed for the cells at $38^{\circ} \mathrm{C}$ and $21^{\circ} \mathrm{C}$. Considering the low gas production (Figure 5), the mass loss in the cell at $12^{\circ} \mathrm{C}$ can be considered principally caused by leaching.

The mass loss obtained by leaching and gas production was compared to the mass loss obtained directly, i.e. by subtracting the total dry weight of the sample at the opening of the cells from its weight in the beginning. Figure 11 presents the mass losses obtained from tests performed at $38^{\circ} \mathrm{C}$, a much higher temperature than what is experienced within DBP covers, in temperate climates. As a consequence, the tests at $38^{\circ} \mathrm{C}$ represent a "worst case scenario" in terms of mass loss that might affect the performance of the DBP layer. As shown in Figure 11, the losses are expressed in terms of variation of dry mass and of percentage of dry mass lost from DBP. The indirect mass loss accounts for an average of $78 \%$ of the mass loss calculated directly. The latter represents the maximum possible (or 100\%) loss at any stage. Several potential sources of error may explain the origin of these differences, including leakages from the gas bags. According to the mass report following a laboratory study on the degradation of domestic wastes, Barlaz and Ham (1989) identified errors associated with various measurements (volume and gas composition), precision of physico-chemical analyses and unaccounted carbon converted to cell mass. 


\section{Impact of biodegradation on geotechnical parameters and properties}

For mineral soils, volume changes are related to changes in void ratio by the following equation:

[2] $\frac{\Delta V}{V}=\frac{\Delta e}{\left(1+e_{0}\right)}$

However, the results presented in Table 4 show that the equality in Equation 2 does not hold for DBP. Given that the samples were not subjected to any confining load, small increases in volume were observed (less than $2 \%$ in all but one case). These volume changes were accompanied by a 10 to $25 \%$ decrease in density and 17 to $30 \%$ increase in void ratio. The values obtained for the right-hand side of Equation 1 are many times greater than those found for $\Delta \mathrm{V} / \mathrm{V}$. Increases in void ratio were greater for samples that were subjected to biodegradation for a longer period of time. The increase in void ratio without a corresponding change in volume can only be explained by the loss of solid matter due to leaching and gas production associated with biodegradation (Figure 10).

From these results, it can be concluded that without confinement of the deinking byproduct layer, an increase in its hydraulic conductivity with time can be expected. In several sites in Quebec where DBP have been used as part of the cover system, a 30-cm thick soil layer (equivalent to a $10 \mathrm{kPa}$ overburden) was placed over the DBP layer (Audet et al. 2002; Cabral et al. 2002). Field results (unpublished data) and laboratory experiments with large ( $0.6 \times 0.6 \times 0.5$ m) samples (Gharbi 2002) showed that such level of confinement is sufficient to induce a continuous compression of the DBP layer with time, thus resulting in a reduction in hydraulic conductivity. 
Figure 12 shows that the decrease in volatile matter content resulting from the degradation of DBP causes an increase in the water content of the samples, therefore a decrease in the dry mass of the DBP. Each point represents the average of 18 points ( 9 points per cell, two cells open at a time). The values for $\mathrm{t}=0$ represent the averages of the eleven cells (Table 4 ). Considering that the percentage of variation of the water content is always greater than the percentage of the void ratio increment, the degree of saturation must increase accordingly. In all cases, the relationship e.Sr $=$ Dr.w is respected. Furthermore, the relative density increases very little, with the exception of cells 9 and 10, for which the greatest variations in mass, volume, density and void ratios were observed. In this case, the loss in organic matter (less dense than the loss of mineral matter) could be at the origin of this increase in relative density.

The density-water content relationship (Standard Proctor curve) for sample KF 08/06/99 is presented in Figure 13, where the data obtained for the different samples tested after their exhumation can also be found. It can be observed that the biodegradation of the samples did not significantly influence the density-water content relationship, since the values obtained remain similar to that determined for fresh DBP.

\section{GENERAL DISCUSSION ABOUT THE EVOLUTION OF BIODEGRADATION AND ITS IMPLICATIONS FOR A DBP COVER}

The evolution of biogas production and of the quality of the leachate collected during the tests was qualitatively compared to the behaviour dictated by the models routinely used to establish the evolution of anaerobic degradation in sanitary landfill sites. According to these models, the stabilization process is divided into four or five phases described below (Barlaz and

Ham 1989; Farquhar and Rovers 1973; Fuller et al. 1979; Tchobanoglous et al. 1993). It must be 
noted, however, that the conditions under which degradation occurs in cover systems and in MWDF are rather different. Indeed, DBP are compacted to minimize the hydraulic conductivity and are placed with a much higher degree of saturation than solid wastes. Under more saturated conditions, gas exhaustion is slowed, which in turn slows the degradation process itself, thus the amount of biogases generated.

Figure 14 presents the evolution of the gas and leachate composition during the first 150 days of the series of tests at $38^{\circ} \mathrm{C}$. The same degradation behaviour of solid wastes buried in MWDFs (phases I to IV) is observed. During Phase I (aerobic), which lasted 5 days, organic substances, such as sugars and volatile fatty acids, are easily metabolized by fungi and aerobic bacteria resulting in quick oxygen consumption. During Phase II (acidic anaerobic; hydrolysis and fermentation), which took place between the 6 th and $37^{\text {th }}$ day, there was an intense production of $\mathrm{CO}_{2}$ and the production of a leachate with a high VOC content. Phase III (unstable methanogenic), which began around the $37^{\text {th }}$ day and ended on the $113^{\text {th }}$ day, represents the transition between the acid and stabilization phases of $\mathrm{CH}_{4}$ production. During this phase, the volumic concentration of $\mathrm{CH}_{4}$ increased rapidly and around the $75^{\text {th }}$ day, represented $40 \%$ of the gas formed. From the $113^{\text {th }}$ day, it can be observed that the process had reached Phase IV (stable methanogenic), during which the $\mathrm{CH}_{4}$ concentration is greater than that of $\mathrm{CO}_{2}$ and the biogas production rate due to degradation of the DBP remains constant and the concentration of organic matter in the leachate is low. This low concentration of dissolved organic matter seems to indicate that the consumption of organic substances occurs as it is solubilized. Thus, it appears that there would be no volatilization from DBP. However, the methanogenic phase does not represent the end of hydrolysis and fermentation. Hydrolysis and fermentation continue, but the methanogenic population increases until the point where the consumption rate of the final products 
approaches the hydrolysis rate. In other words, "methanogenic syntrophy" is reached, i.e. the point in time from which the degradation process steps are in equilibrium (McBean et al. 1995).

Considering the steady gas production after 400 days of the study, it is clear that Phase V, which is characterized by the end of the degradation process, i.e. the end of $\mathrm{CH}_{4}$ and $\mathrm{CO}_{2}$ production, has not yet begun. Regarding the tests at $21^{\circ} \mathrm{C}$ and $12^{\circ} \mathrm{C}$, it is possible to state that the controls at $21^{\circ} \mathrm{C}$ have reached Phase IV (see Figures 6 and 14a), but that they are slightly delayed compared to the tests at $38^{\circ} \mathrm{C}$. There still remains a certain "accumulation" of dissolved substances (Figure 8) and the gas production is lower than that obtained for the cells at $38^{\circ} \mathrm{C}$ (Figure 5). The cell at $12^{\circ} \mathrm{C}$ produced a negligible amount of gas (Figure 5). Since there is no transformation of the dissolved substances to gas, the leachate remains loaded even after the leaching periods. It can be suggested that hydrolytic and fermentative bacteria are less sensitive to temperature and continue to hydrolyze as long as the DBP are leached out of the system.

The degradation of organic materials, such as DBP, can be explained, in a simplified way, as a transfer of mass between three phases or physical states: solid, liquid and gas. This transfer also summarizes in a certain way, the methanogenic syntrophy phases (Augenstein and Pacey 1991; Barlaz and Ham 1989; Farquhar and Rovers 1973; Fuller et al. 1979; Rees 1980). The solid phase is the source of carbon and nutrients for the development of micro-organisms, while the liquid phase (water) occupies the voids. As the degradation advances, solubilization of the solid components of the DBP occurs by degradation and/or chemical solubilization. The solubilization changes the characteristics of the liquid phase, which becomes a leachate loaded with organic and dissolved inorganic substances. The third phase, known as the gaseous phase, is highly dependent on the liquid phase, since $\mathrm{CH}_{4}$ production needs simple carbon sources, which become available through hydrolysis and fermentation. 
As shown in Figure 15, the micro-organism-mediated interactions between these three phases (gaseous, liquid and solid) result in mass loss over the long term, both through leaching and gas production. In the beginning of the degradation process, the mass loss is mostly caused by the solubilization of the substances in the solid phase. This loss causes an accumulation of dissolved substances in the leachate, which is characteristic of the acidic phase of anaerobic digestion. In the case of the laboratory tests, a part of the accumulated substances was leached out. In the case of the 1st leaching period, the mass loss was significant (Figure 9). In the absence of percolation, mass loss occurs by gas production (Figure 9).

\section{Biodegradation in the field}

Analysis of unpublished field results by Teixeira (2001) show that the pore water is not purged as fast as in the laboratory. According to calculations made by Teixeira (2001) using lysimeter data (Table 5), if only vertical percolation by advection is considered, it can be estimated that the pore water would have advanced around $0,8 \mathrm{~m}$ in 4 years, i.e. $40 \%$ of the total thickness of a 2-m thick DBP layer above the lysimeter. The mass loss (dry basis) would be approximately $0.6 \%$ per year, clearly indicating that mass loss by leaching is a slow process. It can, therefore, be evaluated that at least 10 years would be necessary for one EVV to be completely leached out of the system in the field. This would correspond to an accumulated mass loss of $6 \%$.

In Table 5, the flow rate considered (35 1/year) was taken from calculations made by Cabral et al. (2002). The percentage of mass loss equals the ratio between the mass lost and the total solid mass in the DBP column from the top of the lysimeter until the surface. The 
concentration of total solids, $30000 \mathrm{mg} / \mathrm{l}$, corresponds to the concentration found at a depth of $1.0 \mathrm{~m}$ in observation wells, in the beginning of the monitoring period (Teixeira 2001).

Gas production rates in DBP covers constructed in Quebec have not been determined and the study of dynamics of mass loss under field conditions requires further investigation. But, given the slow pace of leaching, the high $\mathrm{CH}_{4}$ concentrations obtained below actual DBP layers (from 40 to $60 \%$ according to Audet et al. 2002, i.e. within the range that is characteristic of phases III and IV of anaerobic digestion), and the decrease in concentration of several parameters mentioned above, it is suggested that mass loss in compacted DBP layers would be mainly associated with gas production.

Gas production in the field can be roughly estimated using the rate of production determined in the laboratory for the test at $12^{\circ} \mathrm{C}$, which is the one that best represents actual conditions within a DBP cover layer. According to Teixeira (2001), the rate of gas production at $12^{\circ} \mathrm{C}$ is in the vicinity of $0.8 \% / \mathrm{yr}\left(\mathrm{CH}_{4}\right.$ and $\mathrm{CO}_{2}$ combined), whereas for tests performed at higher temperatures, a rate of up to $4.2 \% / \mathrm{yr}$ was obtained. Given the fact that temperatures can reach $25^{\circ} \mathrm{C}$ at a depth of one meter inside a DPB layer, it would be reasonable to consider a rate of production between $0.8 \% / \mathrm{yr}$ and $4.2 \% / \mathrm{yr}$.

\section{CONCLUSIONS}

This paper presented a laboratory testing program whose main goal was to evaluate the accelerated biodegradation behaviour of DBP, a material rich in organic matter that is increasingly used in cover systems at mining tailings and landfill sites. The experimental program included a series of tests performed under three different temperatures: 12,21 and $38^{\circ} \mathrm{C}$. The first simulated field conditions, the second simulated the temperature that prevails in the 
upper part of the layer of DBP during summer and fall, whereas the last $\left(38^{\circ} \mathrm{C}\right)$ is the ideal temperature to accelerate the anaerobic degradation process. The evolution of gas and leachate production (quality and quantity) was monitored for 400 days. During four periods of approximately one month, deaerated, deionized, distilled water was leached through the samples.

Overall, the results obtained showed that the biodegradation evolution of the DBP placed as part of a cover system may result in: oxygen consumption, production of a leachate loaded with organic and dissolved inorganic substances, gas production, mass loss (from the DBP material itself), changes in void ratios and changes in water content.

The production of an organic rich leachate is an important issue, as far as the use of DBP in mine tailing reclamation projects is concerned, both in terms of the longevity of the barrier and its effectiveness as $\mathrm{O}_{2}$ barrier. According to the results obtained, the level of biodegradation reached in the laboratory after 400 days of testing (expressed, among others, in the form of mass loss) does not seem to adversely affect the behaviour of a DBP cover.

The evolution of the production of biogas and leachate during the DBP degradation tests followed the behaviour of anaerobic degradation in sanitary landfill sites. In the beginning (Phase I), $\mathrm{O}_{2}$ was consumed quite rapidly. During Phase II, there was a significant accumulation of dissolved substances in the leachate. This concentration tended to decrease with time (Phases III and IV), as a result of gas production and leaching. Once the process reached equilibrium, a greater accumulation of dissolved substances in the leachate, due to the transformation to gas, (cell at $38^{\circ} \mathrm{C}$ and $21^{\circ} \mathrm{C}$ ) was observed. In fact, the laboratory tests at $38^{\circ} \mathrm{C}$ and at $21^{\circ} \mathrm{C}$ demonstrated that, even during the periods without leaching, there was a decrease in the concentration of dissolved materials, which was caused by gas production at rates that quickly became constant. The final stabilization phase (Phase V), where degradation stops, was not 
reached during the 400 days of monitoring. Consequently, it wasn't possible to evaluate the extent of the ultimate degradation.

At the end of the tests, the mass losses by leaching (between 5\% and $6 \%$ ) were similar for all the tests, without respect to temperature. In the long term, at $38^{\circ} \mathrm{C}$, the mass loss due to gas production was greater than the loss from leaching ( $8 \%$ for the former, $5 \%$ for the latter). The mass loss from leaching and gas production corresponds to approximately $78 \%$ of the loss calculated by the difference of the solid mass before and after each test. This recovery rate can be considered satisfactory given the numerous potential sources of error associated with this type of study. Among the identified sources of error are those associated with measurements (volume and gas composition), uncertainties associated with the physico-chemical analysis methods and limitations of the methods for estimating dissolved gas concentration, potential gas leaks, etc.

Monitoring of the evolution of selected geomechanical and hydraulic parameters showed that the degradation caused an increase in water content, which was expected. There was a slight swelling of the DBP (due to the absence of a minimum overburden) and a substantial increase in void ratio at the end of the tests. The increase in void ratio was greater for the tests that lasted longer. The increase in void ratio without a corresponding change in volume can only be explained by loss of solid matter due to leaching and gas production. Normally, an overburden of around $10 \mathrm{kPa}$ would cause a decrease in the void ratios, thus of hydraulic conductivity.

\section{ACKNOWLEDGEMENTS}

Funding for this study was provided by Industries Cascades Inc., Perkins Papers Ltd. and NSERC (Canada) under the University-Industry partnership grant number CRD 192179. Support received by the first author from the CNPq (Brazil) is also greatly appreciated. The authors also 
acknowledge the help provided by Jean-Guy Lemelin and Éric Drouin in the design of the cell and measuring system as well as with the experimental testing.

\section{REFERENCES}

American Public Health Association, American Water Works Association, and Water Environment Federation 1995. Standard methods for the examination of water and wastewater $19^{\text {th }}$ ed. American Public Health Association.

ASTM 1987. D 2974: Standard test methods for moisture, ash, and organic matter of peat and other organic soils, American Society for Testing and Materials, Philadelphia, $4 \mathrm{p}$.

ASTM 2000. D 698: Standard test methods for laboratory compaction characteristics of soil using standard effort, American Society for Testing and Materials, Philadelphia, $11 \mathrm{p}$.

ASTM 2001. E1721-01 Standard test method for determination of acid-insoluble residue in biomass, American Society for Testing and Materials, $3 \mathrm{p}$.

Audet, C., Lefebvre, G., Cabral, A.R., and Burnotte, F. 2002. State of development in the valorization of deinking by-products as an alternative to fine grained soils. In TAPPI 2002, Montréal, March 2002.

Augenstein, D., and Pacey, J. 1991. Modeling landfill methane generation. In Sardinia 91 - Third International Landfill Symposium, pp. 115-148.

Barlaz, M.A. Carbon storage during biodegradation of municipal solid waste components in laboratory-scale landfills. Global Biogeochemical cycles, vol 12, No. 2, pp. 373-380, June 1998.

Barlaz, M.A. 1997. Mibrobial studies of landfills and anaerobic refuse decomposition. In Manual of Environmental Microbiology. American Society for Microbiology, New York. pp. 541557. 
Barlaz, M.A., and Ham, K. 1989. Mass-balance analysis of anaerobically decomposed refuse. Journal of Environmental Engineering, 115(6): 1088-1102.

Boman, B., and Bergstrom, R. 1985. Anaerobic treatment of fiber sediment and forest industry wastewater sludge, Report IVL Report B792, Swedish Environmental Research Institute, Stockholm, Sweden, p.

Brown, R.A., Fourie, A.B., and Snyman, R. 1998. Pulp sludge: waste or valuable capping material? In Fourteenth Congress of the Institute of Waste Management, Kempton Park, South Africa, October 1998, pp. 564-579.

Bureau de Normalisation du Québec 1986a. Sols - Détermination de la densité relative, Report CAN/BNQ 2501-070-M-86, Conseil canadien des normes, Ottawa, 7 p.

Bureau de Normalisation du Québec 1986b. Sols - Détermination de la relation teneur en eaumasse volumique, Report CAN/BNQ 2501-250-M86, Conseil canadien des normes, Ottawa, $12 \mathrm{p}$.

Cabral, A.R., Tremblay, P., and Lefebvre, G. 2004. Determination of the diffusion coefficient of oxygen for a cover system composed of pulp and paper residues. Geotechnical Testing Journal, 27(2): 184-197.

Cabral, A.R., Racine, I., Burnotte, F., and Lefebvre, G. 2000. Diffusion of oxygen through a pulp and paper residue barrier. Canadian Geotechnical Journal, 37: 201-217.

Cabral, A.R., Burnotte, F., Lefebvre, G., and Panarotto, C.T. 2002. Geotechnical characterization of a pulp and paper (deinking) residue used in cover systems. In 4th International Conference on Environmental Geotechnics. Edited by L.G. de Mello and M.M. Almeida, Rio de Janeiro, Brazil. Balkema, Vol.1, pp. 207-212. 
Cabral, A.R., Burnotte, F., Lefebvre, G., Amyot, G., and Lacasse, G. 1999. Design construction and monitoring of a waste rock cover using pulp and paper residues. In Tailings and Mine Waste '99, Fort Collins, Colorado, January 24-27. Balkema, pp. 405-415.

Cabral, A.R., Lefebvre, G., Burnotte, F., Proulx, M.-F., Racine, I., and Audet, C. 1998. Developments in the use of deinking residues in cover systems for acid generating mine tailings. In Tailing and Mine Waste '98, Balkema, pp. 379-388.

Christensen, T.H., and Kjeldsen, P. 1989. Basic biochemical processes in landfill. In Sanitary Landfill: process, technology and environmental impact. Academic Press Limited, London. pp. 29-49.

CQVB 1996. Campagne de caractérisation des résidus papetiers, Centre Québécois de Valorisation des Biomasses et de Biotechnologies Bibliothèque Nationale du Québec, 208 p. Ettala, M. 1993. Quality of deinking sludge. J. Environ. Sci. Health, A28(4): 923-932.

Farquhar, G.J., and Rovers, F.A. 1973. Gas production during refuse decomposition. Water, Air, and Soil Pollution, 2: 483-495.

Floess, C.H., Smith, R.F.J., and Hitchock, R.H. 1995. Capping with fiber clay. Journal of Civil Engineering: 62-63.

Fuller, W.R., Alesii, B.A., and Carter, G.E. 1979. Behavior of municipal solid waste leachate composition variations. Journal Environmental Science Health Letters, 14(60): 461-485.

Gharbi, M. 2002. Étude de la compressibilité à long terme des matériaux organiques: les sousproduits de désencrage. M.Sc.A., Université de Sherbrooke, Sherbrooke, 105 p.

Hartz, K.E., Klink, R.E., and Ham, R.K. 1982. Temperature effects: methane generation from landfill samples. Journal of Environmental Engineering, 108(4): 629-638. 
Jackson, M.J., and Line, M.A. 1997. Composting pulp and paper mill sludge - effect of temperature and nutrient addition method. Compost Science, 5(1): 74-81.

Kamon, M., Inazumi, S., Rajasekaran, G., and Katsumi, T. 2002. Evaluation of waste sludge compatibility for landfill cover application. Soils \& Foundations, 42(4): 13-27.

Kraus, J.F., Benson, C.H., Van Maltby, C., and Wang, X. 1997. Laboratory and field hydraulic conductivity of three compacted paper mill sludges. Journal of Geotechnical and Geoenvironmental Engineering, 123(7): 654-662.

LaPlante, K. 1993. Geotechnical investigation of several paper mill sludges for use in landfill covers. Master thesis, Rensselaer Polytechnic Institute, Troy, New York, United States, 86 p.

Latva-Somppi, J., Tran, H.N., Barham, D., and Douglas, M.A. 1994. Characterization of deinking sludge and its ashed residue. Pulp \& Paper Canada, 95(10): T382 - T385.

Malmstead, M.J., Bonistall, D.F., and Van Maltby, C. 1999. Closure of a nine-acre industrial landfill using pulp and paper mill residuals. TAPPI Journal, 82(2): 153-160.

Maltby, C.V., and Eppstein, L. 1994. A field case study of the use of paper industry sludges as hydraulic barriers in landfill cover systems. In Proceedings of Hydraulic Conductivity and Waste Contaminant Transport in Soil, Philadelphia, pp. 546-558.

McBean, E.A., Rovers, F.A., and Farquhar, G.J. 1995. Solid waste landfill engineering and design. Prentice Hall, Englewood Cliffs, 521 p.

Moo-Young, H.K., and Zimmie, T.F. 1996. Effects of organic decomposition on paper mill sludges used as landfill cover material. In Proceedings of 2nd International Conference on Environmental Geotecnhics. Edited by B. M.Kamon, Osaka, Japan, pp. 827-832.

Rees, J.F. 1980. Optimization of methane production and refuse decomposition in landfills by temperature control. Journal of Chemical Technology and Biotechnology, 30: 458-465. 
Tchobanoglous, G., Theisen, H., and Vigil, S. 1993. Integrated Solid Waste Management Engineering Principles and Management Issues. In Water Resources and Environmental Engineering. McGraw-Hill, United States of America, p. 978.

Teixeira, C.E. 2001. Evolution biochimique des résidus de désencrage dans un contexte de valorisation comme barrière de recouvrement. Ph.D. Thesis, Université de Sherbrooke, Canada, 209 p.

Trépanier, L., Gallichand, J., Caron, J., and Thériault, G. 1996. Environmental impact of on-farm storage of deinking paper mill sludge. Transactions of the ASAE, 39(5): 1853-1859.

Vlyssides, A.G., and Economides, D.G. 1997. Characterization of wastes from a newspaper wash deinking process. Frenesius Environmental Bulletin, 6: 734-739.

Wiegand, P.S., and Unwin, J.P. 1994. Alternative management of pulp and paper industry solid wastes. TAPPI Journal, 77(4): 91-97.

Young, L.Y., and Frazer, A.C. 1987. The fate of lignin and lignin-derived compounds in anaerobic environments. Geomicrobiol. J., 5(3/4): 261-293.

Zeikus, J.G., and Winfrey, M. 1976. Temperature limitation of methanigenesis in aquatic sediments. Applied and Environmental Microbiology, 31(1): 99-107.

Zimmie, T.F., and Moo-Young, H. 1995. Hydraulic conductivity of paper sludges for landfill covers. In Geo-environment 2000, pp. 932-946. 
Table 1. Average conditions of the DBP placement in the cells

\begin{tabular}{lcc}
\hline Parameter & PVC cells & Plexiglas cell $\left(12^{\circ} \mathrm{C}\right)$ \\
& $(14$ cells $)$ & $(1$ cell $)$ \\
\hline Total height $(\mathrm{cm})$ & $17.9 \pm 0.1$ & 15 \\
Sample volume $\left(\mathrm{cm}^{3}\right)$ & $5628.4 \pm 32.2$ & 2717.6 \\
Dry mass $(\mathrm{g})$ & $2317.7 \pm 24.9$ & 1091 \\
Dry density $\left(\mathrm{kg} / \mathrm{m}^{3}\right)$ & $411.8 \pm 5.8$ & 401.5 \\
Water content $(\%)$ & $172.3 \pm 3.1$ & 180.6 \\
Degree of saturation $(\%)$ & $89.9 \pm 0.6$ & 91.3 \\
Void ratio & $3.7 \pm 0.1$ & 3.9 \\
\hline
\end{tabular}


Table 2. Stoichiometric potential of $\mathrm{CO}_{2}$ and $\mathrm{CH}_{4}$ production per $\mathrm{kg}$ of cellulose and hemicellulose in the DBP placed in the cells

\begin{tabular}{lccc}
\hline & Cellulose & Hemicellulose & Total \\
\hline Mass $(\mathrm{kg})$ & 0.8 & 0.2 & 1.0 \\
$\mathrm{CO}_{2}(\mathrm{l})$ & 304.5 & 83.0 & 387.5 \\
$\mathrm{CH}_{4}(\mathrm{l})$ & 237.8 & 61.6 & 299.4 \\
Total $\mathrm{CO}_{2}+\mathrm{CH}_{4}(\mathrm{l})$ & - & - & 686.9 \\
\hline
\end{tabular}


Table 3. Volumes of biogas produced after 400 days of testing and percentage of total potential

\begin{tabular}{|c|c|c|c|c|c|c|c|}
\hline Sample & $\begin{array}{l}\text { Volume } \\
\mathrm{CO}_{2}(1)\end{array}$ & $\begin{array}{c}\mathrm{CO}_{2} \\
\text { (1/kg dry } \\
\text { material) }\end{array}$ & $\begin{array}{l}\text { Volume } \\
\mathrm{CH}_{4}(1)\end{array}$ & $\begin{array}{c}\mathrm{CH}_{4} \\
\text { (1/kg dry } \\
\text { material) }\end{array}$ & $\begin{array}{c}\text { Total } \\
\mathrm{CO}_{2}+\mathrm{CH}_{4} \\
\text { (1) }\end{array}$ & $\begin{array}{l}\text { Total gas } \\
\text { (1/kg dry } \\
\text { material) }\end{array}$ & $\begin{array}{c}\text { Percentage of total } \\
\text { potential (\%) }\end{array}$ \\
\hline Total potential for & & & & & & & \\
\hline $\begin{array}{l}\text { sample at start of tests } \\
\text { (Equation 3-1) }\end{array}$ & 387.5 & - & 299.4 & - & 686.9 & - & 100.0 \\
\hline Samples at $38^{\circ} \mathrm{C}$ & 70.7 & 30.5 & 55.2 & 23.8 & 125.9 & 60.7 & 18.3 \\
\hline Samples at $21^{\circ} \mathrm{C}$ & 51.9 & 22.4 & 30.5 & 13.1 & 82.4 & 42.7 & 12.0 \\
\hline Sample at $12{ }^{\circ} \mathrm{C}{ }^{1}$ & 2.0 & 0.9 & 0.2 & 0.08 & 2.2 & 3.7 & 0.3 \\
\hline
\end{tabular}

${ }^{1}$ Values already adjusted considering that the mass of the sample tested at $12^{\circ} \mathrm{C}$ is lower the mass of the other samples. 
Table 4. Variation of geotechnical parameters in function of cell opening

\begin{tabular}{|c|c|c|c|c|c|c|c|c|c|}
\hline $\begin{array}{l}\text { Cell opening } \\
\text { (elapsed time } \\
\text { in days) }\end{array}$ & $\begin{array}{c}\text { Cell } \\
\text { numbers }\end{array}$ & $\begin{array}{c}\mathrm{V} \text { initial } \\
(\mathrm{V} \text { final }) \\
\mathrm{cm}^{3}\end{array}$ & $\begin{array}{c}\Delta \mathrm{V} / \mathrm{Vinitial} \\
(\%)\end{array}$ & $\begin{array}{c}\text { Initial } \\
\text { density } \\
\text { (final) } \mathrm{kg} / \mathrm{m}^{3}\end{array}$ & $\begin{array}{c}\mathrm{e}_{0} \\
\text { (e final) }\end{array}$ & $\begin{array}{c}\Delta \mathrm{e} /\left(1+\mathrm{e}_{0}\right) \\
(\%)\end{array}$ & $\begin{array}{l}\text { W initial } \\
\text { (w final) } \\
(\%)^{1}\end{array}$ & $\begin{array}{c}\text { Sr initial } \\
\text { (Sr final) } \\
\%\end{array}$ & $\begin{array}{c}\mathrm{D}_{\mathrm{r}} \text { initial } \\
\left(\mathrm{D}_{\mathrm{r}} \text { final }\right) \\
2\end{array}$ \\
\hline \multirow[t]{4}{*}{$1^{\text {st }}(54)$} & 2 & 5.600 & & 416 & 3.691 & & 170.1 & 89.8 & 1.95 \\
\hline & & (NM) & & (NM) & (NM) & & 200.1 & (NM) & (1.96) \\
\hline & 11 & 5.663 & & 408 & 3.777 & & 172.6 & 89.1 & 1.95 \\
\hline & & (NM) & & (NM) & (NM) & & 196.8 & (NM) & (1.97) \\
\hline \multirow[t]{4}{*}{$2^{\text {nd }}(146)$} & 5 & 5.632 & 1.81 & 412 & 3.736 & 14.2 & 172.3 & 89.9 & 1.95 \\
\hline & & $(5.734)$ & & $(361)$ & $(4.408)$ & & (205.0) & $(90.6)$ & $(1.95)$ \\
\hline & 12 & 5.663 & 1.40 & 409 & 3.763 & 14.7 & 172.1 & 89.2 & 1.95 \\
\hline & & $(5.742)$ & & (359) & $(4.462)$ & & $(207.1)$ & $(91.0)$ & (1.96) \\
\hline \multirow[t]{4}{*}{$3^{\text {rd }}(272)$} & 3 & 5.585 & 1.68 & 416 & 3.687 & 19.2 & 171.8 & 90.9 & 1.95 \\
\hline & & $(5.679)$ & & $(350)$ & $(4.589)$ & & $(203.2)$ & $(90.6)$ & (1.96) \\
\hline & 7 & 5.648 & 1.26 & 415 & 3.694 & 21.0 & 169.7 & 89.6 & 1.95 \\
\hline & & $(5.719)$ & & (349) & $(4.678)$ & & $(212.1)$ & (89.7) & (1.98) \\
\hline \multirow[t]{4}{*}{$4^{\text {th }}(400)$} & 6 & 5.663 & 0.51 & 402 & 3.851 & 17.4 & 178.6 & 90.4 & 1.95 \\
\hline & & $(5.692)$ & & 346 & $(4.694)$ & & (211.8) & $(89.0)$ & (1.97) \\
\hline & 9 & 5.600 & 0.18 & 418 & 3.669 & 21.9 & 169.4 & 89.9 & 1.95 \\
\hline & & $(5.610)$ & & $(351)$ & $(4.694)$ & & $(224.5)$ & $(90.0)$ & $(2.0)$ \\
\hline \multirow{4}{*}{$\begin{array}{l}\text { Control at } \\
21^{\circ} \mathrm{C}(400)\end{array}$} & 4 & 5.663 & 1.96 & 406 & 3.808 & 20.1 & 174.0 & 89.1 & 1.95 \\
\hline & & $(5.774)$ & & $(341)$ & $(4.773)$ & & $(225.6)$ & (93.1) & (1.97) \\
\hline & 10 & 5.632 & 3.64 & 418 & 3.670 & 27.8 & 168.0 & 89.3 & 1.95 \\
\hline & & $(5.837)$ & & (341) & $(4.954)$ & & (224.4) & $(92.0)$ & $(2.03)$ \\
\hline \multirow{2}{*}{$\begin{array}{l}\text { Control at } \\
12^{\circ} \mathrm{C}(400)\end{array}$} & 15 & 2.718 & 1.73 & 401 & 3.858 & 13.3 & 179.0 & 91.28 & 1.95 \\
\hline & & $(2.765)$ & & $(358)$ & $(4.502)$ & & $(211.0)$ & $(92.34)$ & $(1.97)$ \\
\hline
\end{tabular}


Table 5. Lysimeter data (Eustis site; lysimeter L1) used to make preliminary estimations of mass loss in the field

\begin{tabular}{ll}
\hline Parameters & Data
\end{tabular}

Dry density in place $\left(\mathrm{kg} / \mathrm{m}^{3}\right)$ 400

Height of the DBP column above the lysimeter (m) 2.0

Lysimeter area $\left(\mathrm{m}^{2}\right)$ 0.23

Total volume of DBP above the lysimeter $\left(\mathrm{m}^{3}\right)$ 0.46

Solid mass $(\mathrm{kg})$ 184

Total solid concentration in the water $(\mathrm{mg} / \mathrm{l})$ 30000

Accumulated volume of water in one year (1) 35

Operational hydraulic conductivity $\left(\mathrm{k}_{\mathrm{op}}\right)(\mathrm{cm} / \mathrm{s})$ $5 \times 10^{-7} \mathrm{~cm} / \mathrm{s}$

Note: Hypothesis of 1-D flow through a totally operational lysimeter. 


\section{List of Figures}

Figure 1. Average composition of the DBP used in the experimental program ( $\%$ by weight)

Figure 2. Diagram of the biodegradation cell

Figure 3. Evolution of gas production

Figure 4. Evolution of the biogas composition

Figure 5. Evolution of cumulated gas production for different testing temperatures

Figure 6. Evolution of the volumetric concentration of $\mathrm{CH} 4$ in the biogas for different testing temperatures

Figure 7. Evolution of: (a) COD, VOA, and pH; (b) TS, TVS and the ratio TVS/TS

Figure 8. Evolution of the: (a) $\mathrm{pH}$; (b) TS; (c) COD; and (d) VOA in the leachate as a function of the testing temperature

Figure 9. Evolution of the total mass loss (gas + leaching)

Figure 10. Evolution of the total mass loss (gas + leaching) as a function of the testing temperature

Figure 11. Comparison between measured total mass loss (gas + leaching) and mass loss obtained by weighing the samples before and after the tests at $38^{\circ} \mathrm{C}$

Figure 12. Evolution of the water content and of the volatile matter

Figure 13. Density-water content relationship (Proctor curve) for the DBP tested

Figure 14. Evolution of (a) gas composition; and (b) $\mathrm{pH}, \mathrm{COD}, \mathrm{VOC}$ and $\mathrm{Ca}++$ in the leachate

Figure 15. Schematic representation of the evolution of mass loss 


\section{$39.7 \%$ NON VOLATILE}

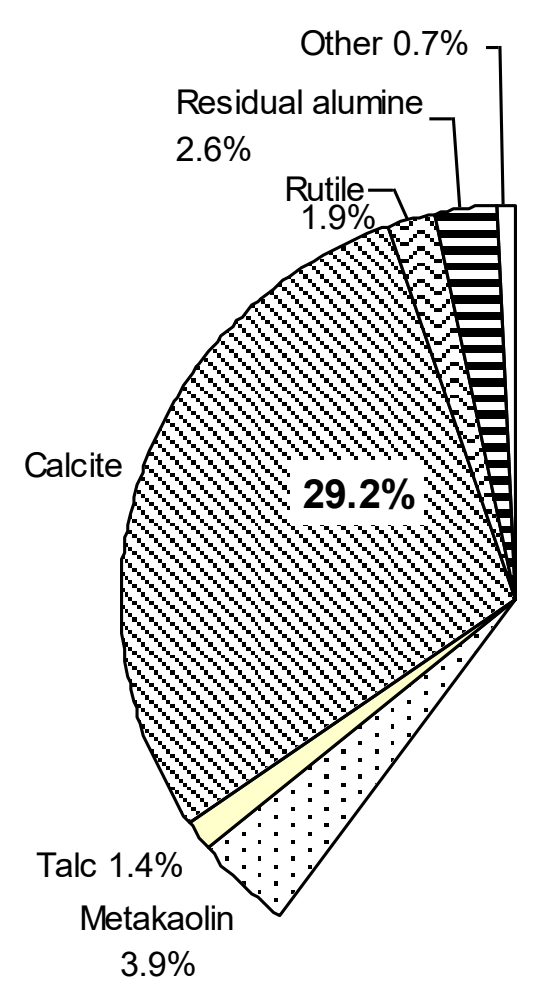

$60.3 \%$ VOLATILE

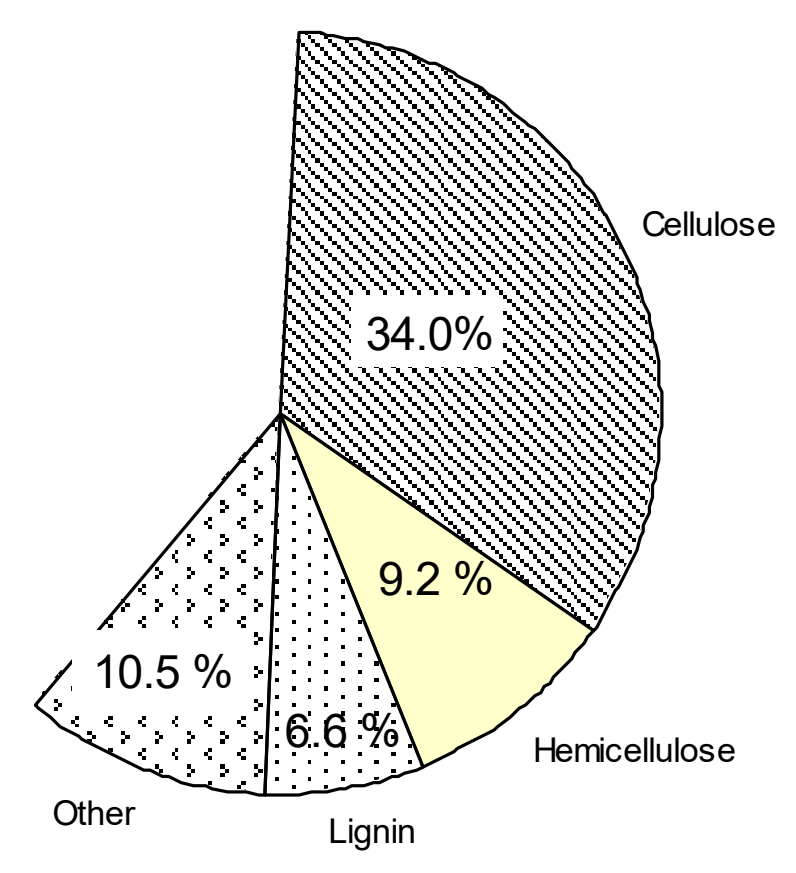




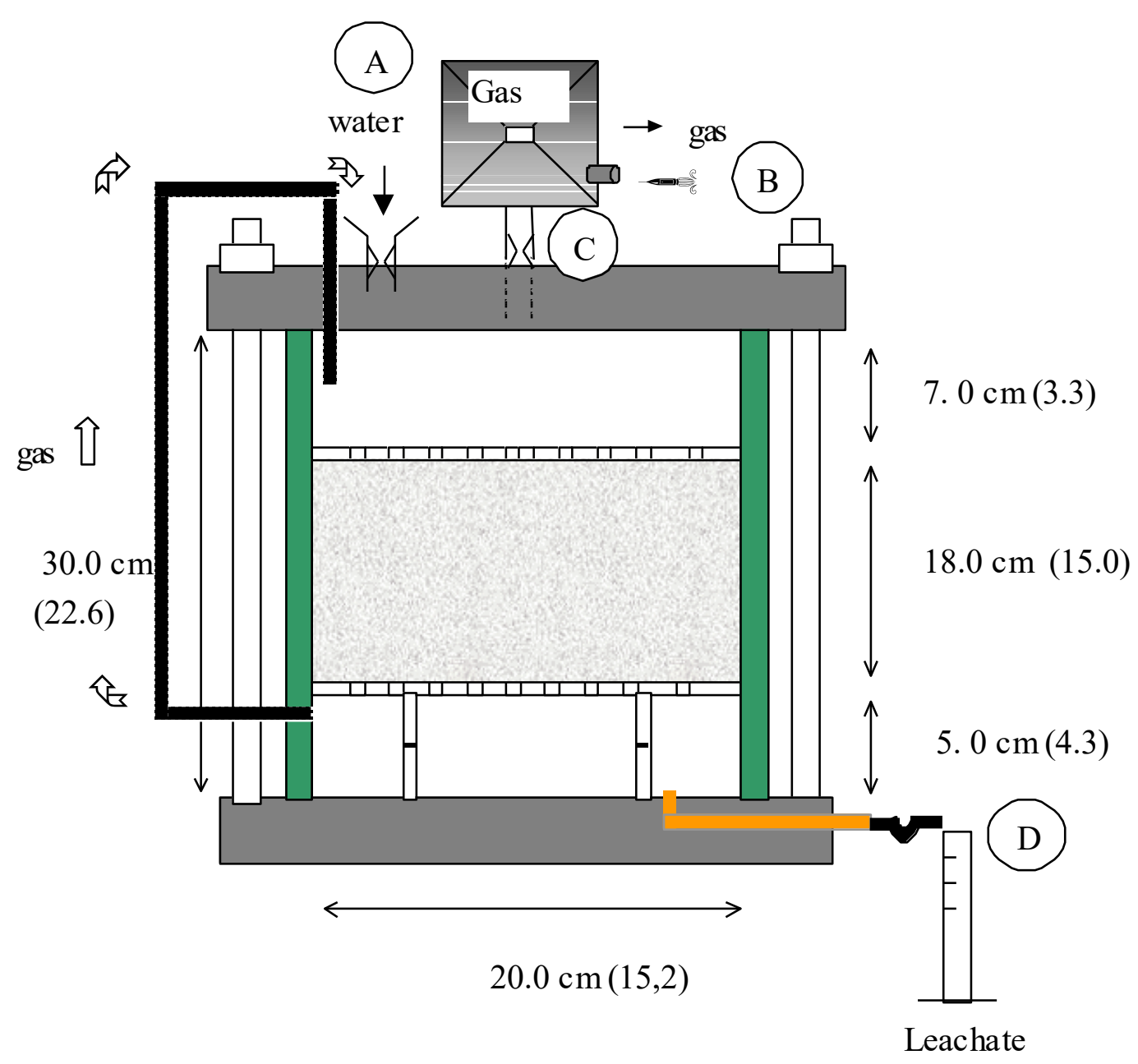




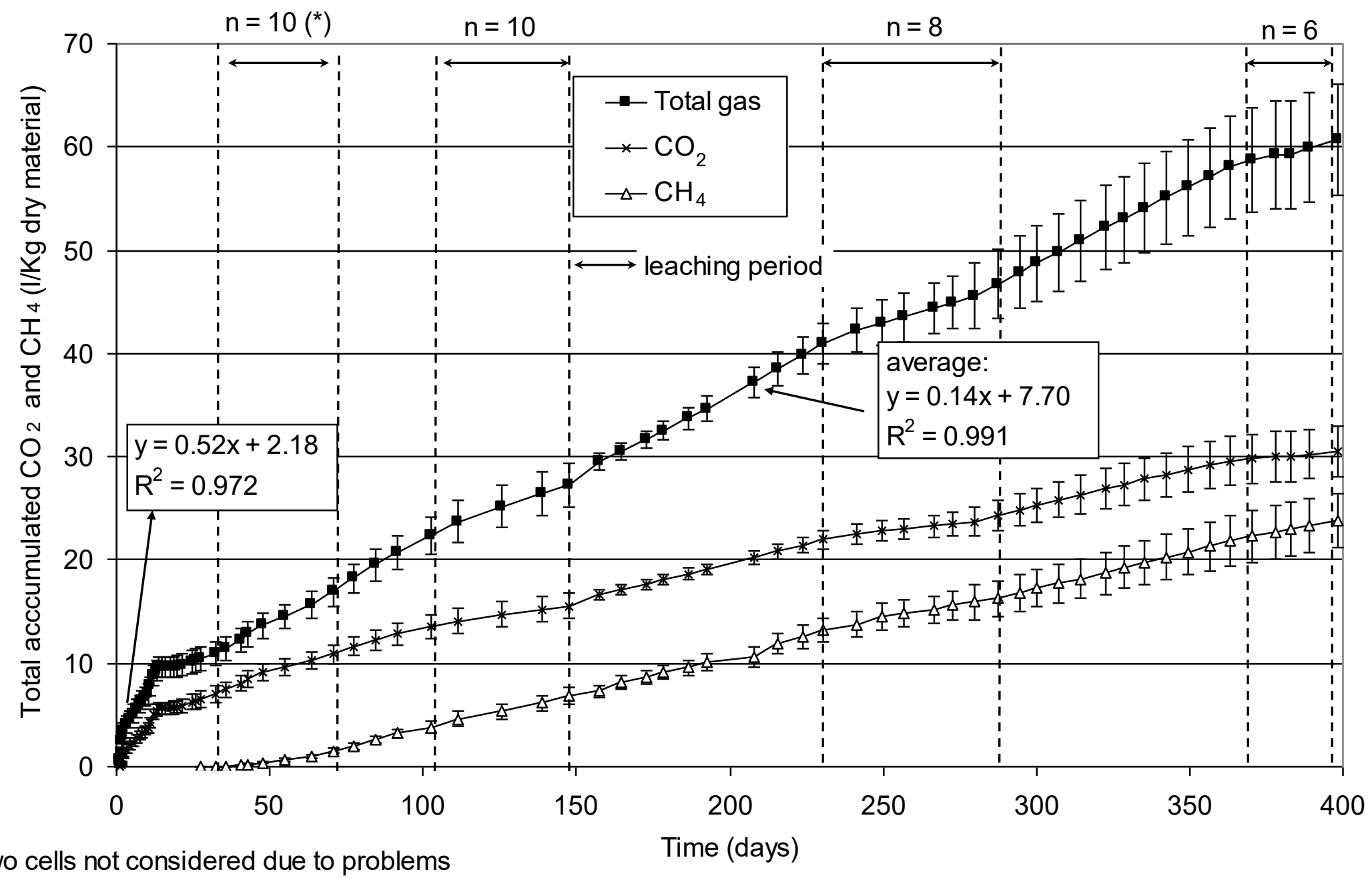

$\left.{ }^{*}\right)$ Two cells not considered due to problems with the gas collection system 


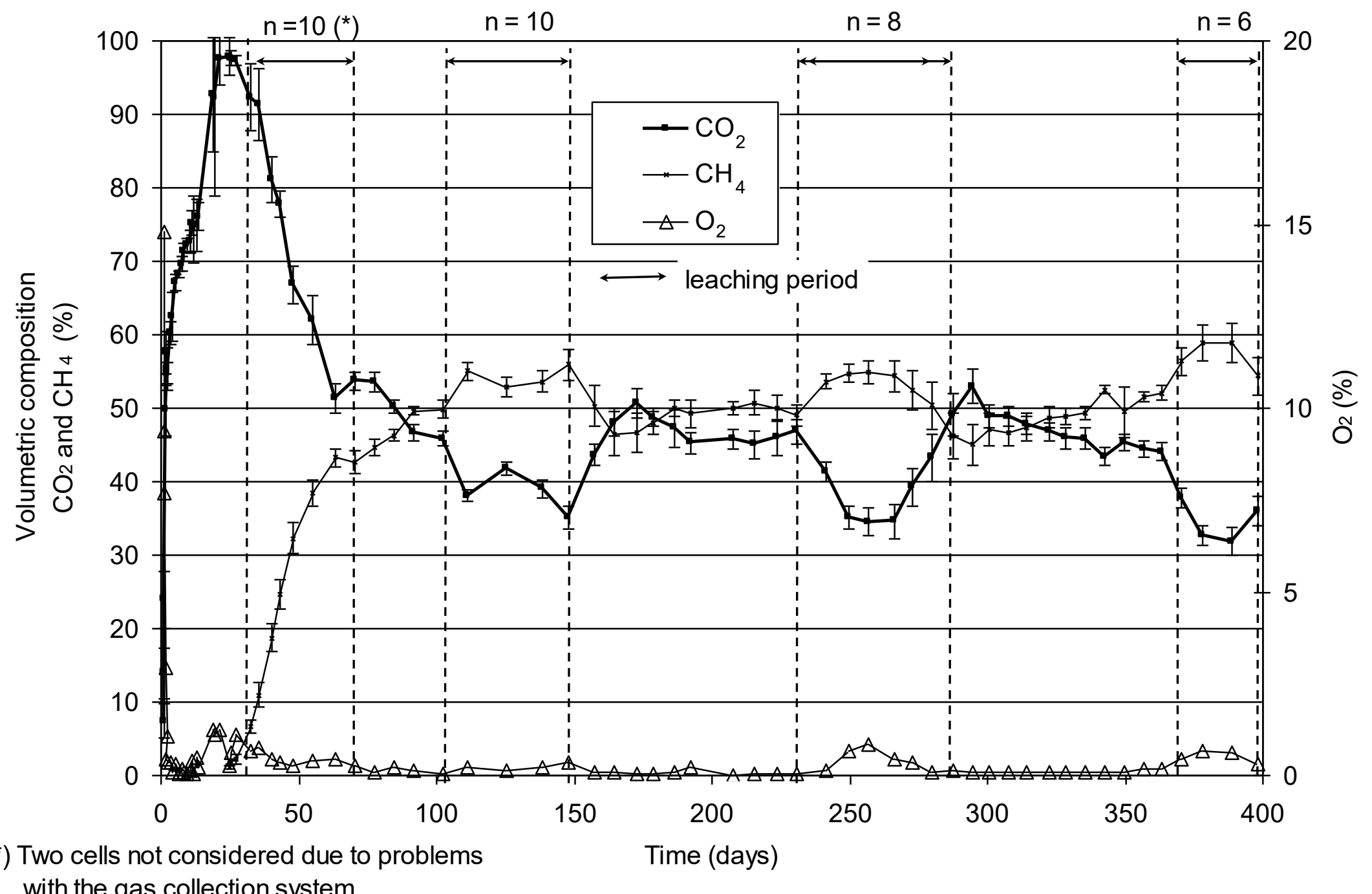

with the gas collection system 


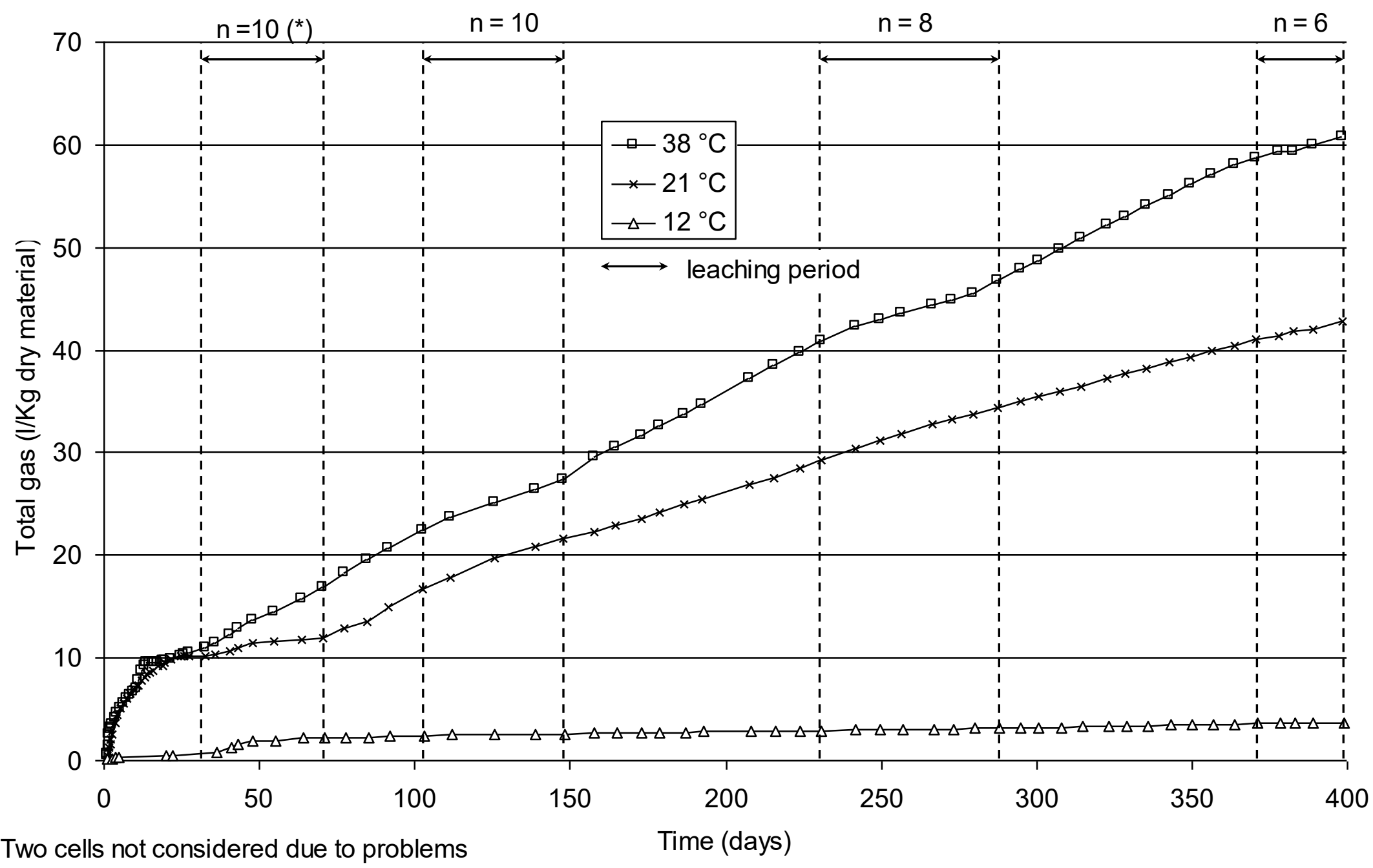

$\left.{ }^{*}\right)$ Two cells not considered due to problems with the gas collection system 


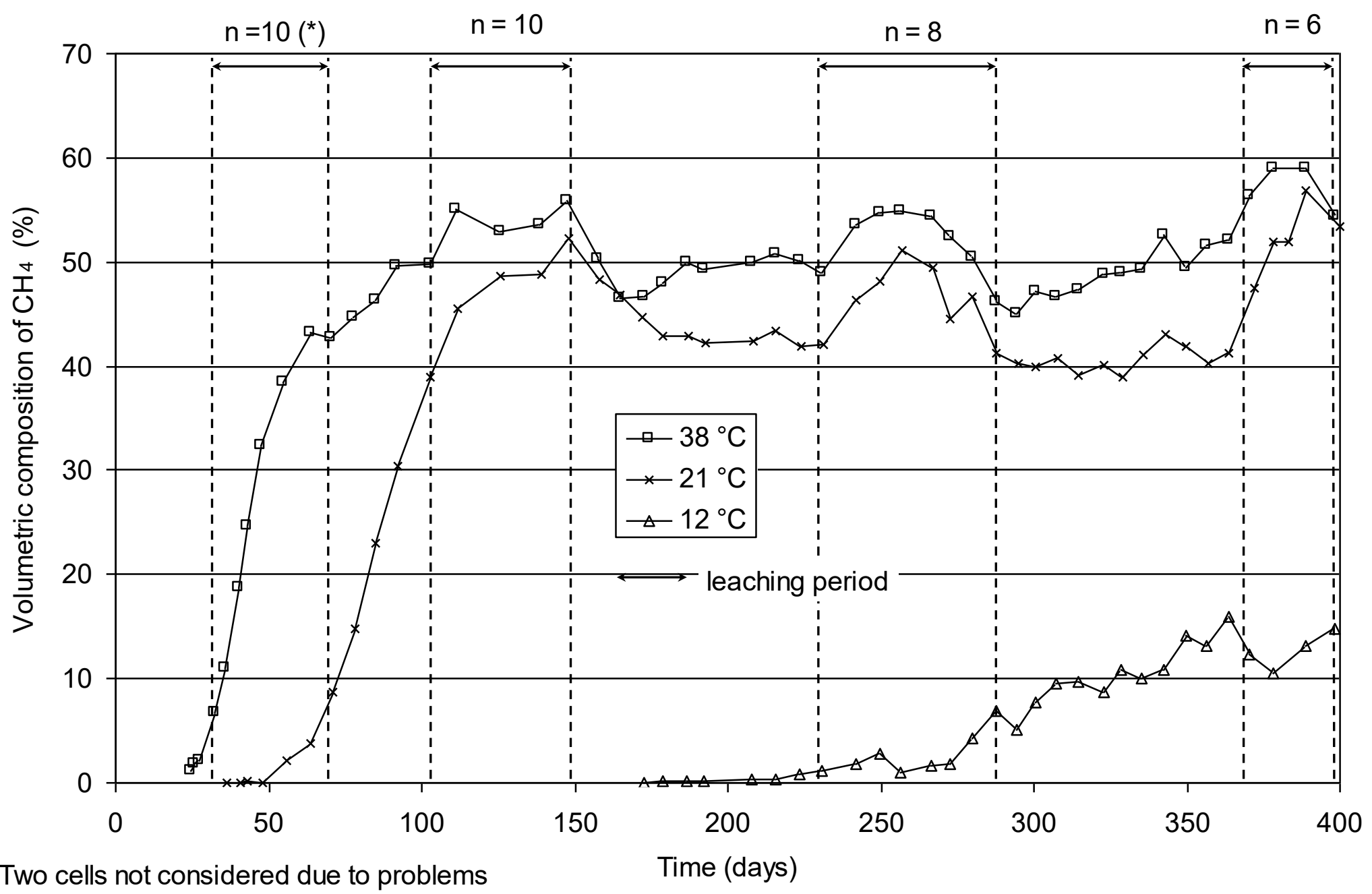

with the gas collection system 
(a)

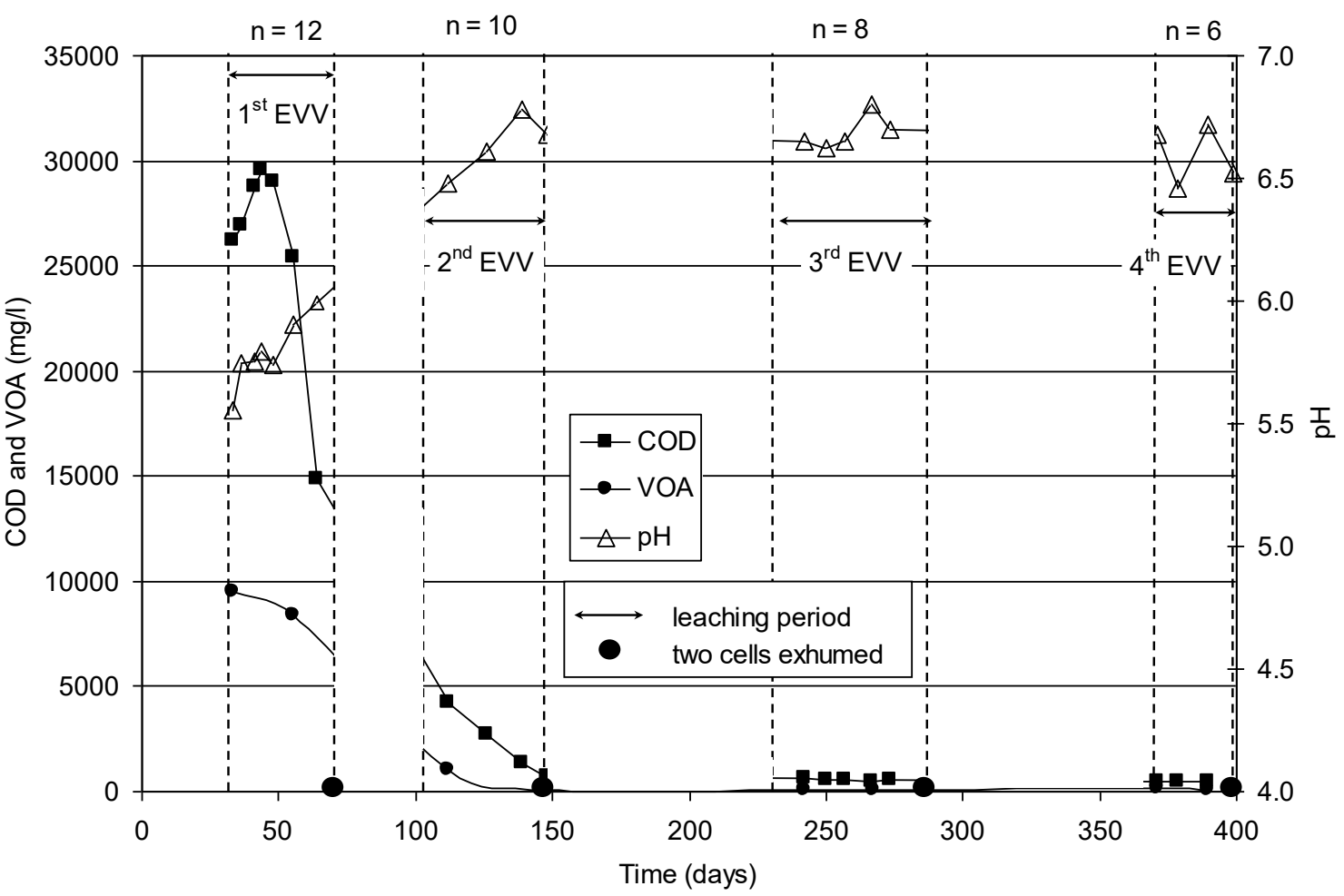

(b)

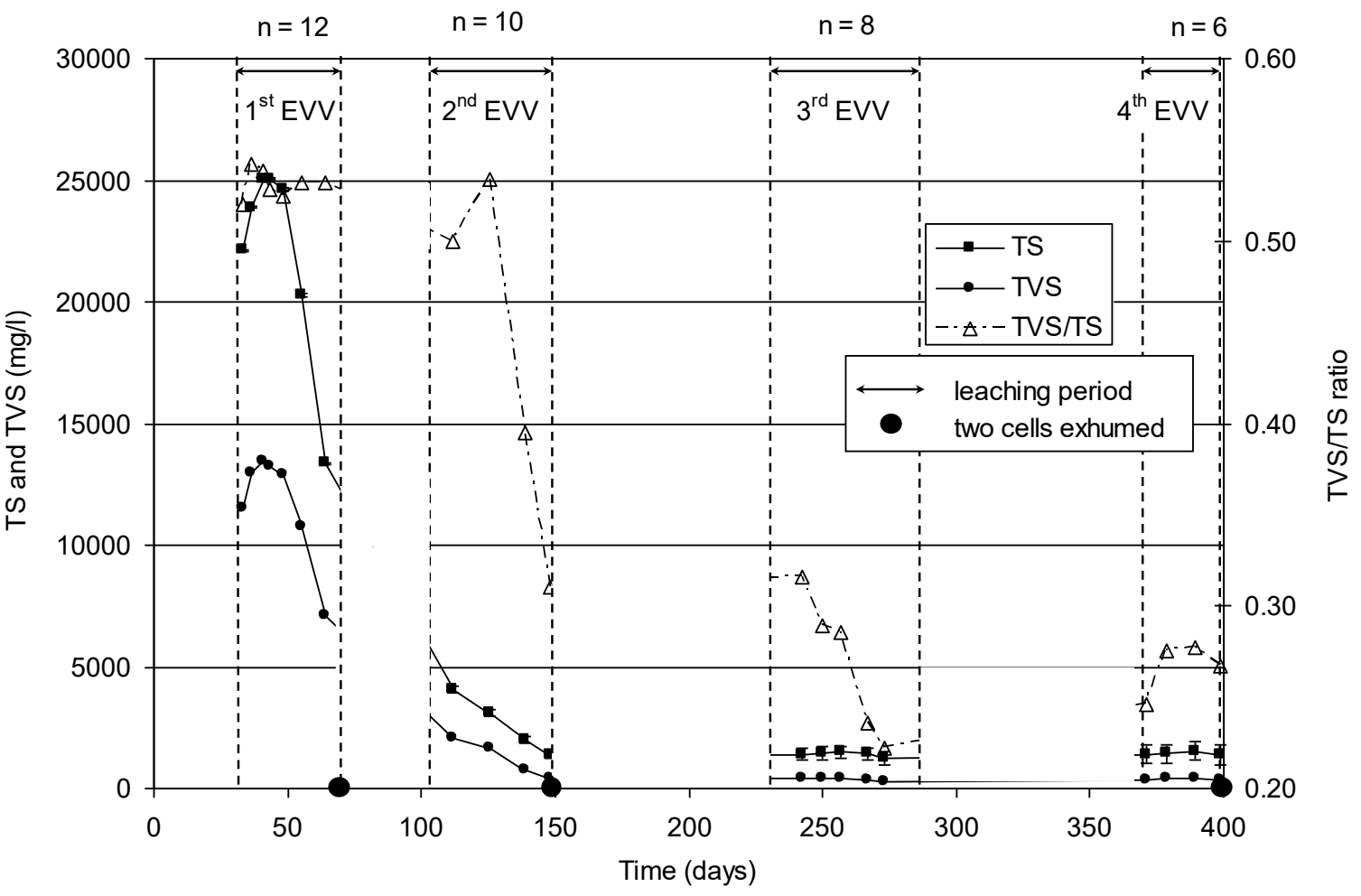


(a)

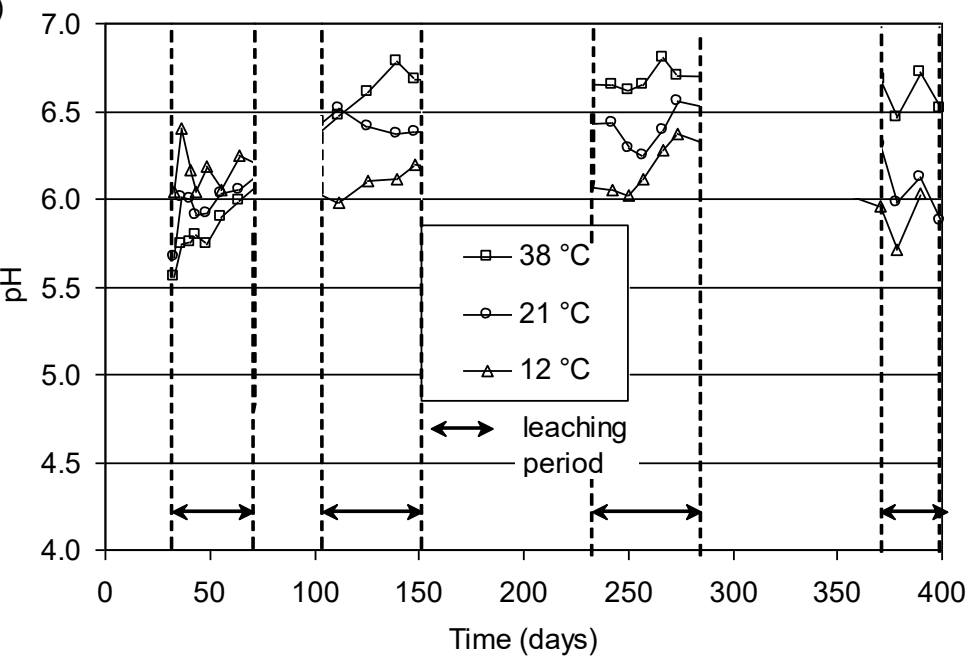

(c)

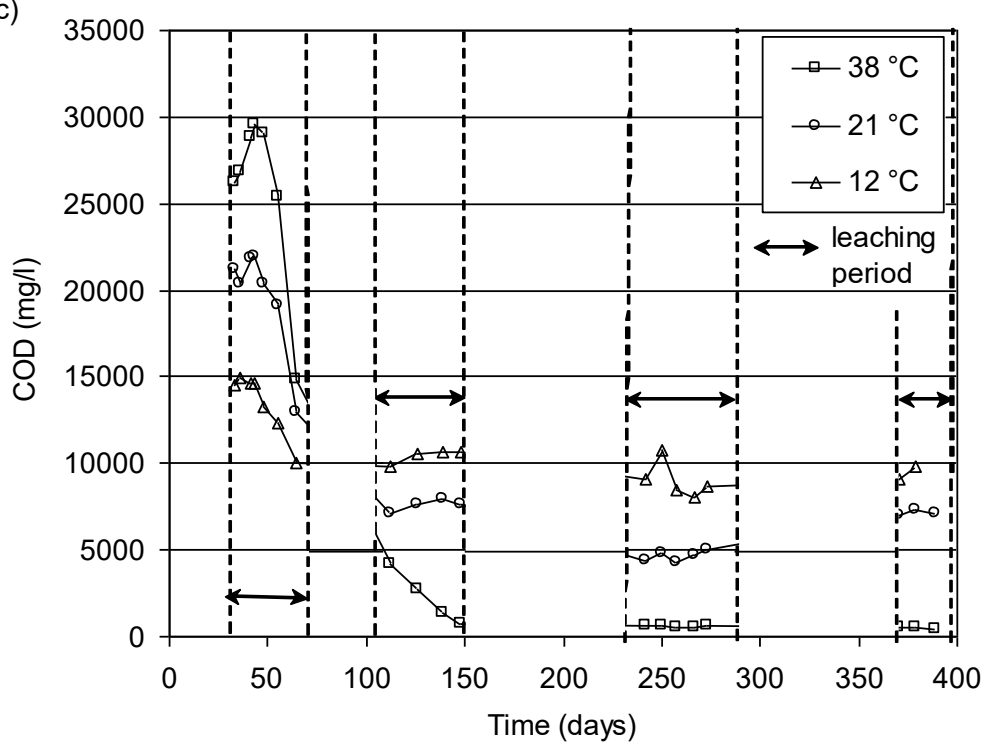

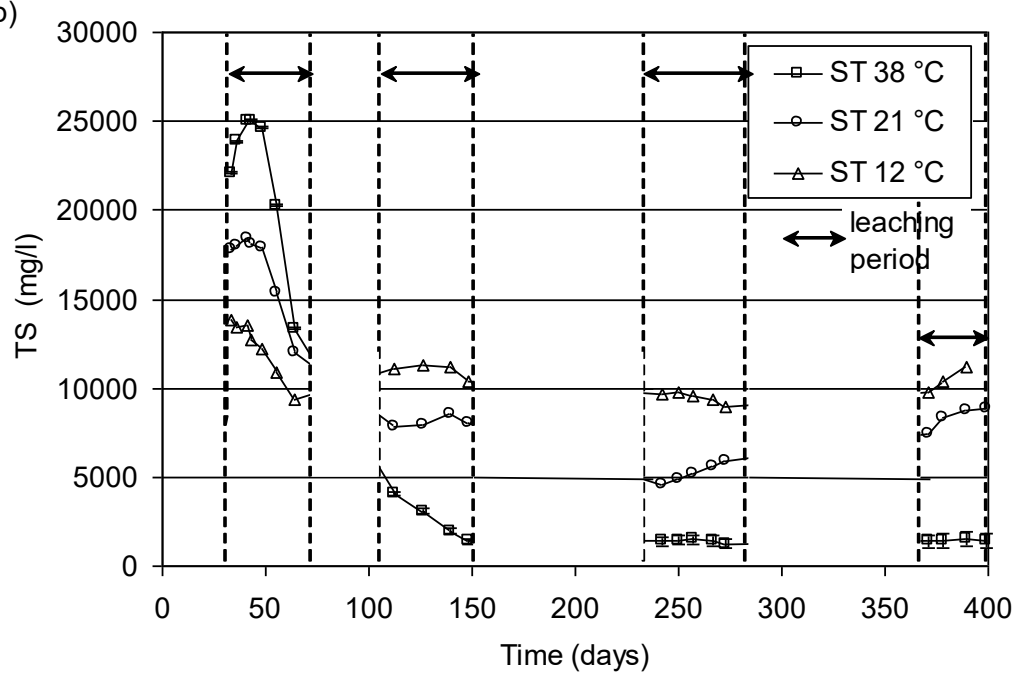

(d)

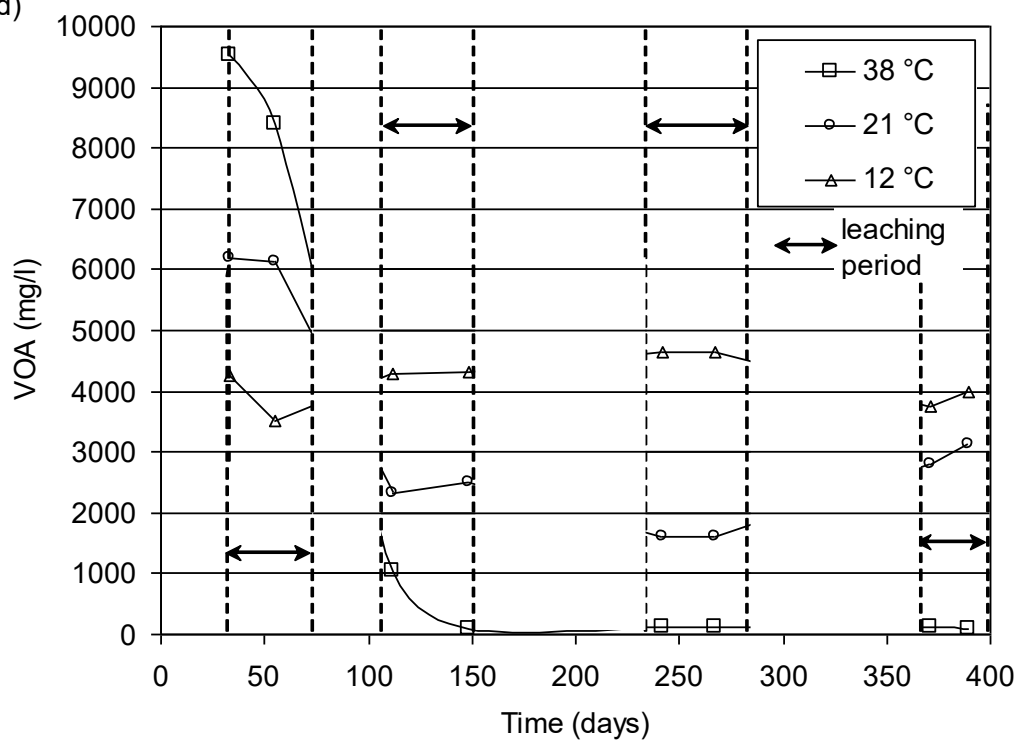




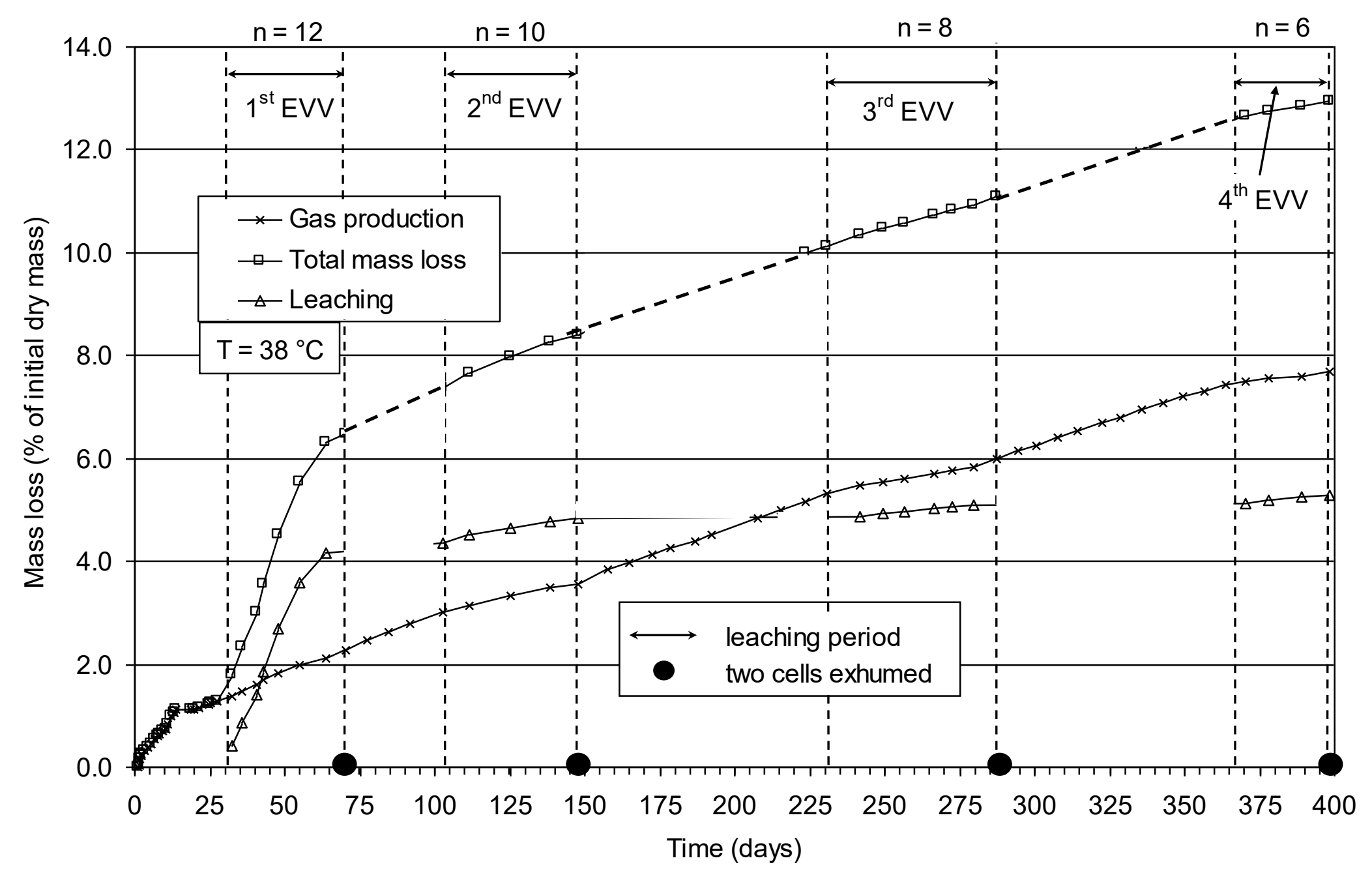




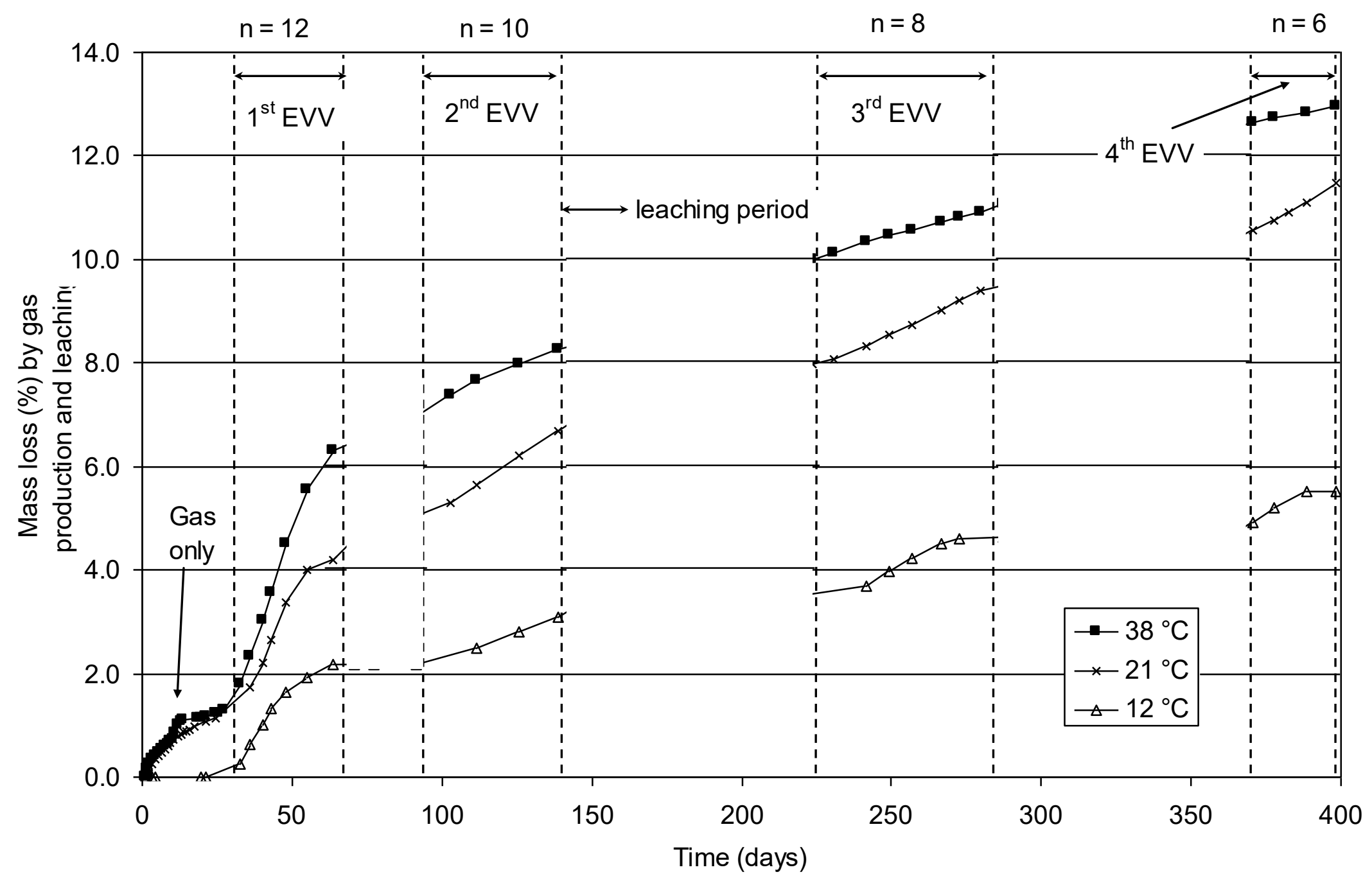




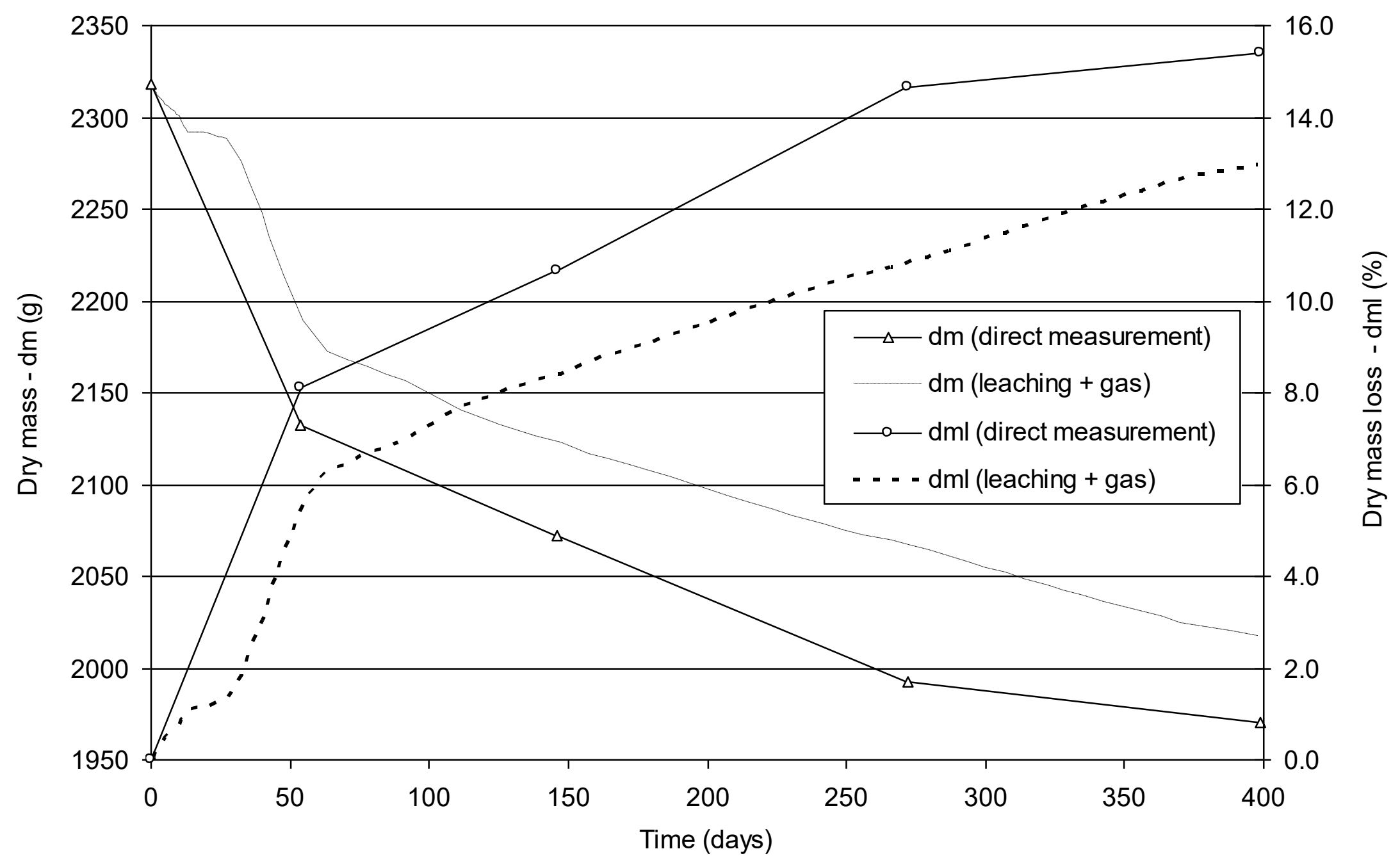




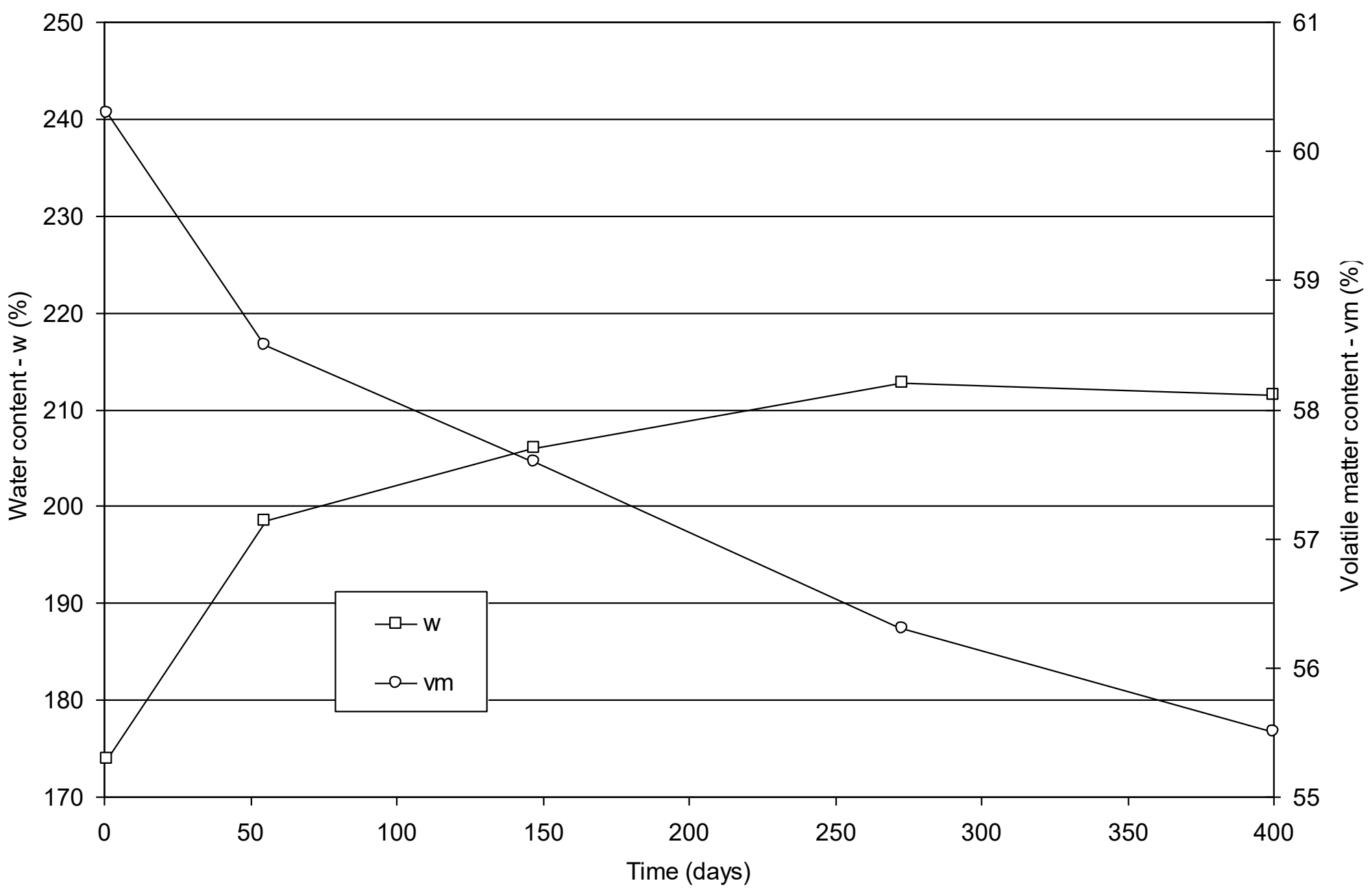


(a)

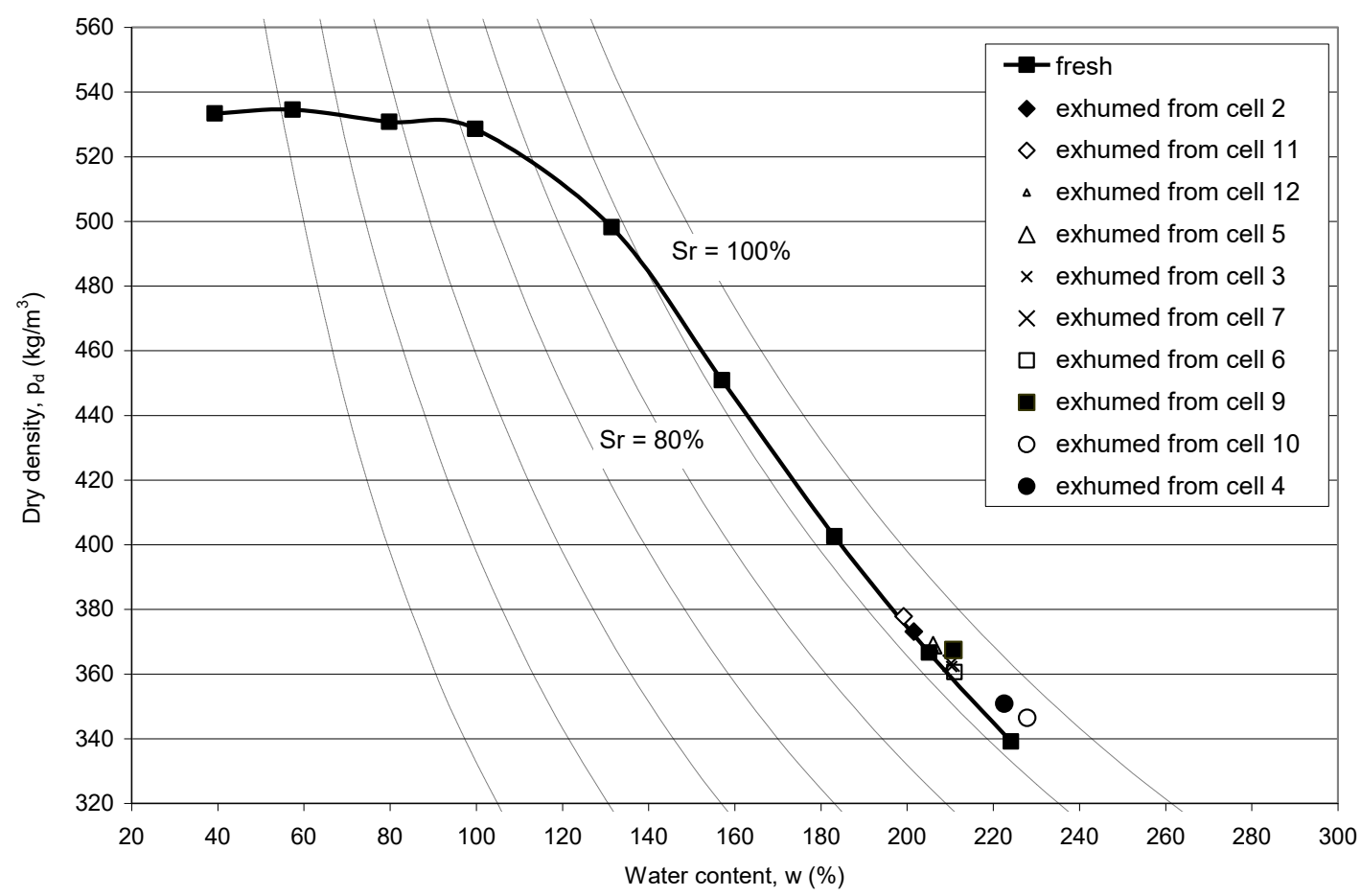

(b)

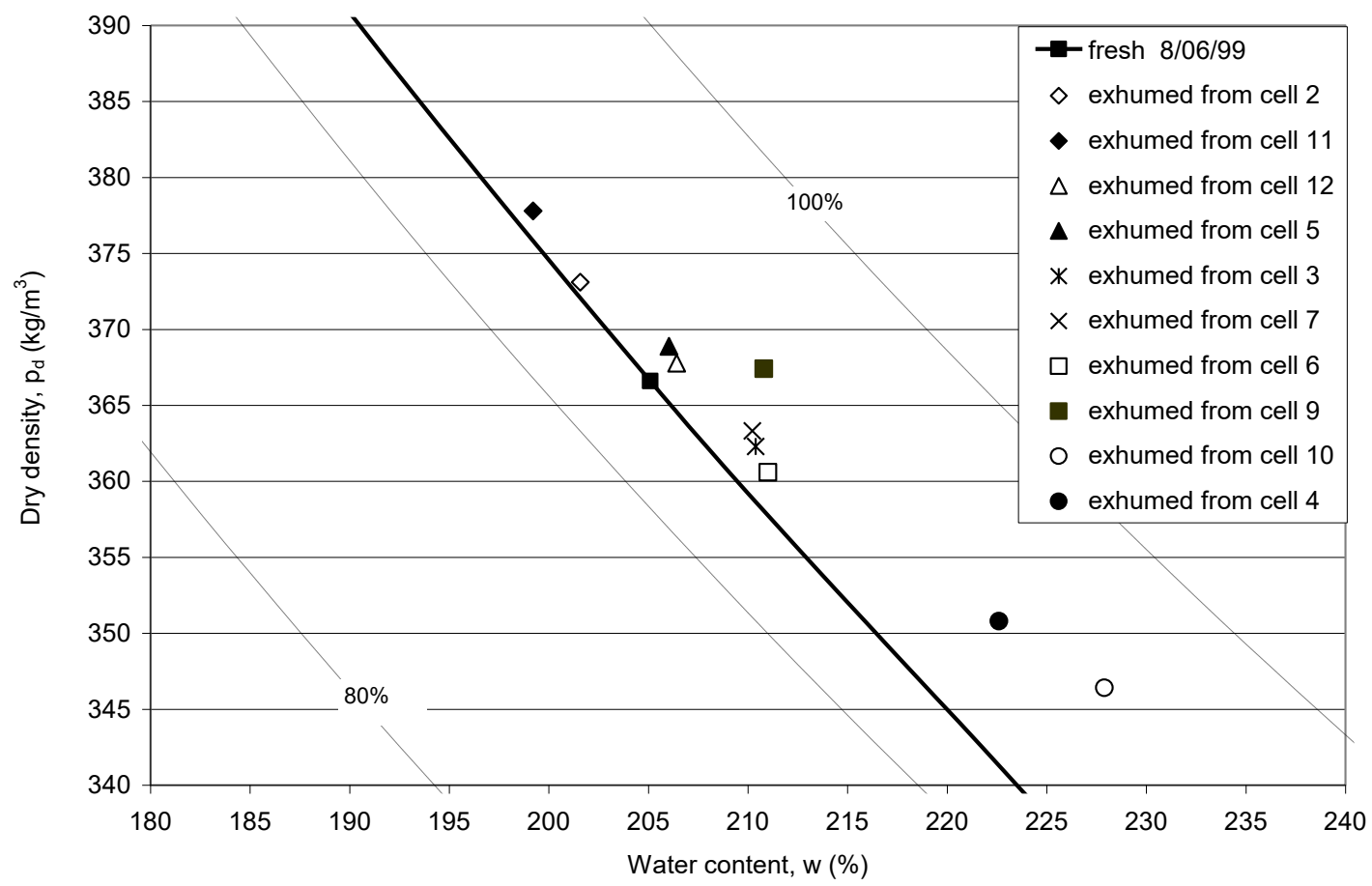


(a)

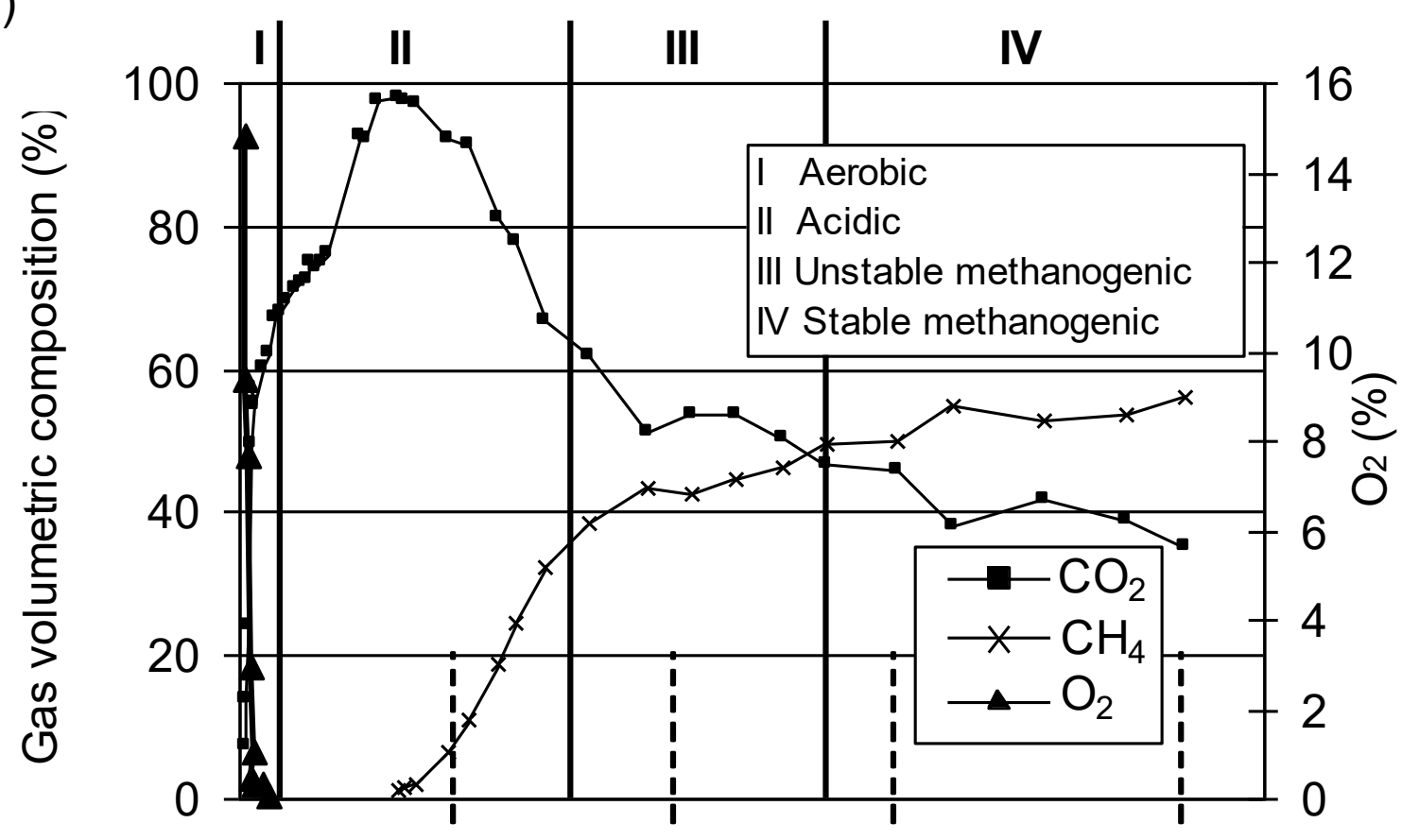

(b)

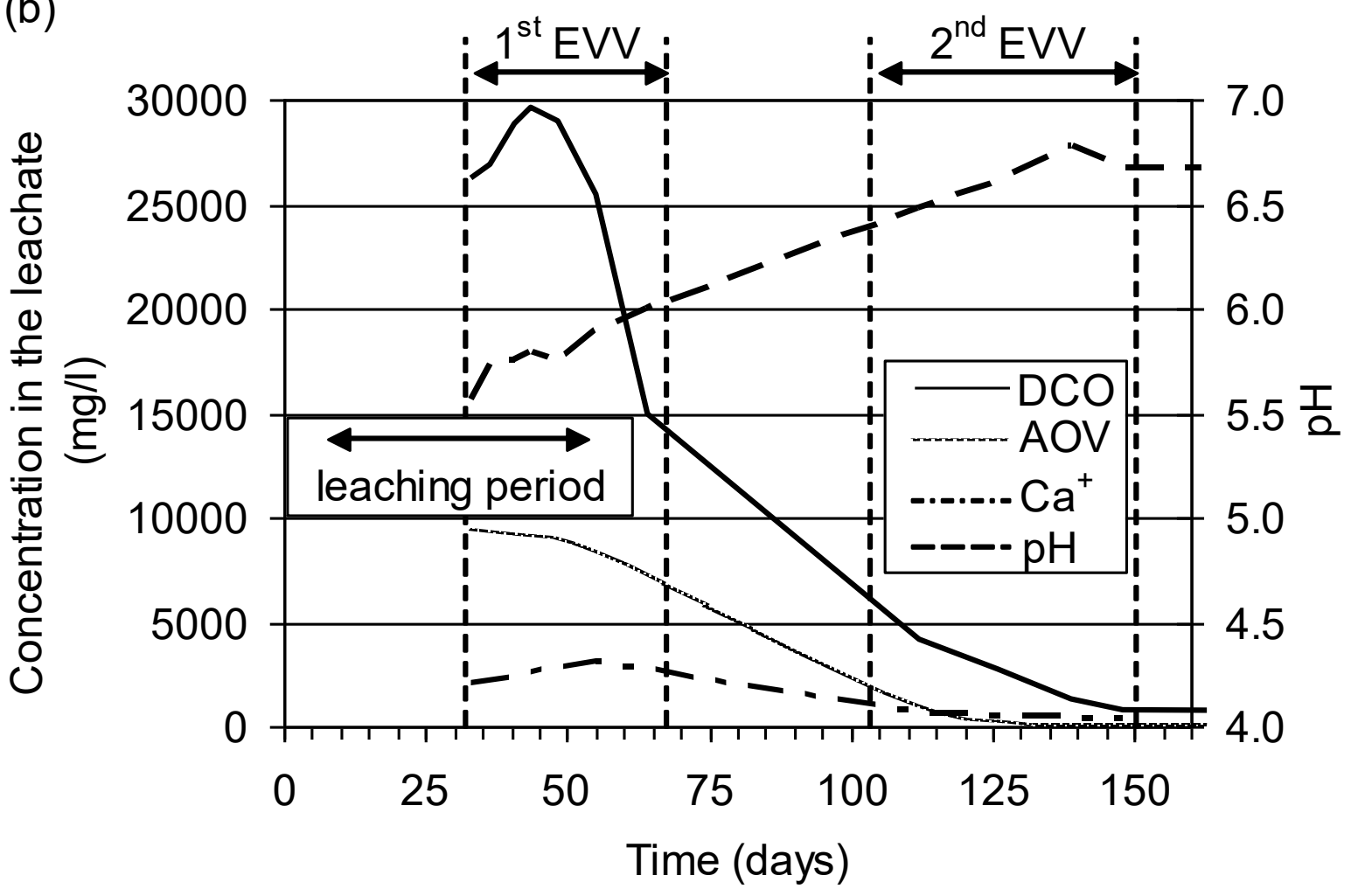




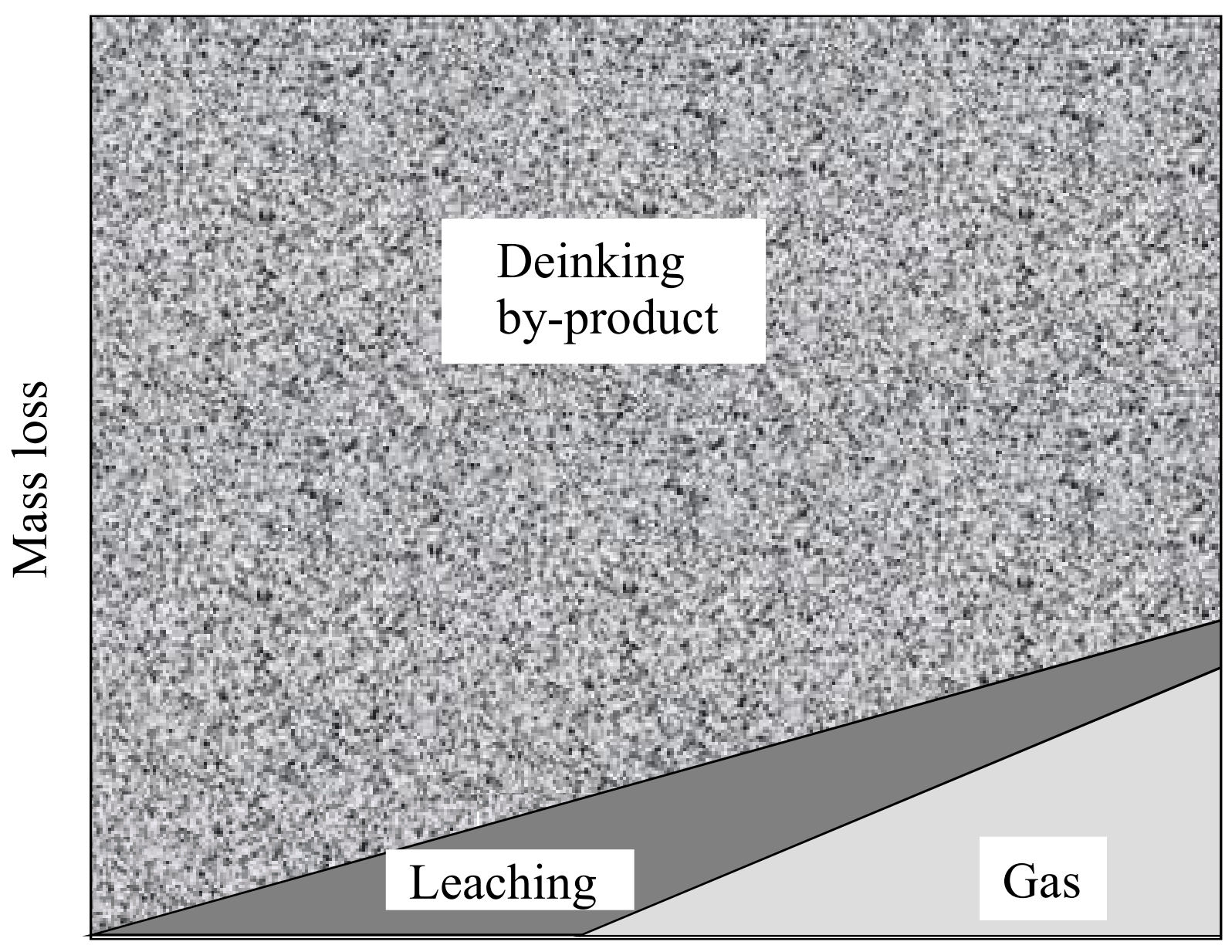

Time 